\title{
Archaeological Research at the Hinjosa Site (41JW8), Jim Wells County, Southern Texas
}

Thomas R. Hester

Center for Archaeological Research

Follow this and additional works at: https://scholarworks.sfasu.edu/ita

Part of the American Material Culture Commons, Archaeological Anthropology Commons, Environmental Studies Commons, Other American Studies Commons, Other Arts and Humanities Commons, Other History of Art, Architecture, and Archaeology Commons, and the United States History Commons

Tell us how this article helped you.

This Article is brought to you for free and open access by the Center for Regional Heritage Research at SFA ScholarWorks. It has been accepted for inclusion in Index of Texas Archaeology: Open Access Gray Literature from the Lone Star State by an authorized editor of SFA ScholarWorks. For more information, please contact cdsscholarworks@sfasu.edu. 


\section{Archaeological Research at the Hinjosa Site (41JW8), Jim Wells County, Southern}

Texas

\section{Creative Commons License}

(c) (1) (8)

This work is licensed under a Creative Commons Attribution-NonCommercial 4.0 International License 


\section{ARCHAEOLOGICGL RESEARCH AT THE HIDOJOSA SITE (41 IU 8), Jim Wells County, Southern Texas}

\section{THOMAS R HESTER}

with the collaboration of

Feris A Bass, Jr. Anne A. Fox, Edwin S. Harris and Thomas C Kelly

Center for Archaeological Research

The University of Texas at San Antonio

Archaeological Survey Report, No. 42 

ARCHAEOLOGICAL RESEARCH AT THE HINOJOSA SITE

(41 JW 8), JIM WELLS COUNTY, SOUTHERN TEXAS

Thomas R. Hester

with the collaboration of

Feris A. Bass, Jr., Anne A. Fox, Edwin S. Harris and Thomas C. Kelly

Center for Archaeological Research

The University of Texas at San Antonio

Archaeological Survey Report, No. 42

1977 

Page

List of Figures... . . . . . . . . . . . . . ii

List of Tables . . . . . . . . . . . . . . . . . ii

Introduction . . . . . . . . . . . . . . . . . . 1

Archaeological Background . . . . . . . . . . . . . 1

Environmental Notes . . . . . . . . . . . . 4

Site Description . . . . . . . . . . . . . . 6

Investigation Procedures . . . . . . . . . . . . 8

Intrasite Features . . . . . . . . . . . . . 13

The Artifacts . . . . . . . . . . . . . . 15

Chronometric Analysis . . . . . . . . . . . . . 27

Palynological Analysis . . . . . . . . . . . . 28

Faunal Remains . . . . . . . . . . . . . . . 29

Molluscan Remains . . . . . . . . . . . . . . . 31

Summary and Recommendations . . . . . . . . . . . 33

Acknowledgments . . . . . . . . . . . . . . 39

References Cited .................. 41 



\section{LIST OF FIGURES}

Figure

Page

1. The Location of Site 41 JW 8 (Hinojosa), Southern Texas . . . . . . . . . . . . 7

2. Map of Site $41 \mathrm{JW} 8$ (Hinojosa) . . . . . . . . . 9

3. Views of Site $41 \mathrm{JW} 8$ (Hinojosa)........... 10

4. Views of Hearth at Site $41 \mathrm{JW} 8$ (Hinojosa) . . . . . . 14

5. Arrow Points from Site 41 JW 8 (Hinojosa) . . . . . 16

6. Lithic Artifacts from Site 41 JW 8 (Hinojosa) . . . . 18

7. Lithic and Shell Artifacts from Site 41 JW 8 (Hinojosa) ................. 19

8. Lithic Artifacts from Site 41 JW 8 (Hinojosa) . . . . 22

9. Ceramics from Site $41 \mathrm{JW} 8$ (Hinojosa) . . . . . . 25

\section{LIST OF TABLES}

Table

1. Grid Coordinates for Excavated Test Pits at Site 41 JW 8 (Hinojosa) . . . . . . . . . . 12

2. A Summary of Faunal Remains at Site 41 JW 8 (Hinojosa)................. 30 

INTRODUCTION

In March 1975, personnel of the Center for Archaeological Research conducted an intensive survey of site $41 \mathrm{JW} 8$ (the Hinojosa site), Jim Wells County, in southern Texas. These investigations were the result of an agreement between the Center and the United States Department of Agriculture (USDA) Soil Conservation Service (SCS) (purchase order no. TX-1102-75). Ear1ier research at the site had consisted of a preliminary surface survey, the results of which were published by Hester and Bass (1974). In their report, recommendations were made for an intensive survey of the site, to include site mapping, intensive surface collecting, and test excavations. A major objective of this program of investigation was to better evaluate the site in terms of its potential eligibility for nomination to the National Register of Historic Places (it was nominated by the State Review Board on January 23, 1976; 1etter from John W. Clark, Jr. to T. R. Hester). It was not known at that time whether the site would be affected by the construction and subsequent impoundment of waters related to proposed Floodwater Retarding Structure No. 5 (Revised) to be built downstream on Chiltipin Creek (Hester and Bass 1974:1-2).

Thus, during the period of March 13-19, 1975, a field team directed by Feris A. Bass, Jr. (Research Associate of the Center) conducted archaeological studies at the site. Following the conclusion of the fieldwork, a preliminary report was submitted to the SCS office in Temple, Texas (letter from T. R. Hester to Logan Crews, Apri1 22, 1975).

\section{ARCHAEOLOGICAL BACKGROUND}

A summary of the archaeological background for the Jim Wells County region has been published by Hester and Bass (1974:2-3). In general, the archaeology of this area of south Texas is extremely poorly known. Hester and Bass (1974) recorded two sites, $41 \mathrm{JW} 7$ and $41 \mathrm{JW} 8$ (Hinojosa). Several other sites (multi-component, with Archaic and Late Prehistoric artifacts) have been reported by Alvin C. Boldt, a local amateur archaeologist (site survey forms on file, Texas Archaeological Research Laboratory, Austin). Three additional sites, in southern Jim Wells County, have been briefly described in a paper by Patterson (1974:12-14). Patterson interpreted the three sites (41 JW 3-5) as being of 
"Late Archaic" age; he was particularly intrigued by the occurrence of burins and blades in the surface lithic assemblages from the sites.

The most significant perspective from which to view the Hinojosa site and its archaeological contents is its relationship to other Late Prehistoric sites documented in southern Texas in recent years. A recent paper includes an overview of the Late Prehistoric evidence from the region (Hester 1975a); and in a monograph prepared by Hester and Hill (1975), a review of Late Prehistoric and Protohistoric occupations in the northwestern sector of southern Texas was presented. A brief summary of these data is given below.

In the coastal zone of southern Texas (the area from just north of Corpus Christi to Brownsville at the mouth of the Rio Grande), two distinctive Late Prehistoric complexes are recognized. In the Corpus Christi vicinity there is the Rockport Complex (Corbin 1974), with a cultural inventory typified by stemmed arrow points (mainly of the Perdiz type), sandy-paste Rockport ceramics (sometimes decorated with asphaltum), and a core-blade industry (Hester and Shafer 1975). Near the mouth of the Rio Grande is the Brownsville Complex (MacNeish 1958; Prewitt 1974), with a material culture dominated by shell artifacts, and reflecting a sophisticated shell-working technology. Peoples of the Brownsville Complex appear to have had trade contacts with Mexico, particularly the Huastecan area, as evidenced by the occurrence of distinctive ceramics, jade and obsidian in some of the Brownsville Complex sites (Hester 1969). Additionally, the Brownsville Complex is noted for the occurrence of numerous cemetery sites (summarized by Hester 1969).

Parts of the interior of southern Texas are not well known in terms of Late Prehistoric sites. While a number of sites have been found, usually characterized by the occurrence of several types of arrow points and occasional sherds of bone-tempered pottery (Hester and Hill 1971), no distinctive patterns have yet been recognized. In some areas, such as the Falcon Reservoir and Starr County districts along the lower Rio Grande of extreme southern Texas, recognizable Late Prehistoric components are extremely rare (cf. Nunley and Hester 1975). In this particular region only a few arrow points have been found, and these are from widely scattered sites (D. Fox and H. Uecker, personal communication). 
In the north central and northeastern sectors of southern Texas, two important Late Prehistoric sites have been published. One is $41 \mathrm{ME} 19$, near Natalia in Medina County (Hester and Kelly 1976). The thin deposits, probably representing a one-time occupation, yielded Perdiz arrow points and bone-tempered ceramics, and had bison bone among the faunal refuse. The second site is Berclair, located in the town of the same name in Goliad County. Hester and Parker (1970) reported Perdiz arrow points, bone-tempered and grog-tempered ceramics, tools made on blades, and large numbers of bison remains. Other Late Prehistoric materials from these two sectors (aside from these two sites) are generally surface finds of Late Prehistoric arrow points, scattered bonetempered ware, etc.

Research in Late Prehistoric sites in the northwestern sector of southern Texas, conducted by T. C. Hill, Jr. and T. R. Hester since 1969, has yielded abundant information on settlement and subsistence systems, 1ithic technology, and chronology of the Late Prehistoric occupations. These data are summarized in a variety of papers and monographs (cf. Hester and Hill 1971; Hill and Hester 1971, 1973; Hester 1974; Hester and Hill 1975; Hester 1970, 1975a,b; Montgomery 1977). While a fairly clear picture is emerging on the Late Prehistoric occupation of this area (particularly in Zavala and Dimmit Counties), it is apparent that there are localized differences among the Late Prehistoric groups. No serious effort has yet been made to define local "phases" or "complexes," although we suspect that these different assemblages reflect the territories of distinct Coahuilteco-speaking peoples. The diversity of the Late Prehistoric remains is evidenced in examining sites of essentially the same age in parallel stream valleys only 20 miles apart (i.e., the ChaparrosaTurkey Creeks drainage and the Tortugas Creek drainage in Zavala County). Along the Chaparrosa-Turkey Creeks drainage, Late Prehistoric sites have predictable distributions, and the contents are remarkably similar (no bison or pottery, but arrow points of the Perdiz, Scallorn and Zavala types, and associated Iithic tools; cf. Hester 1970, 1974; Montgomery 1977). At sites on Tortugas Creek, such as Holdsworth (Hester and Hill 1975) and Tortuga Flat, the cultural remains are quite different--with pottery, bison and antelope remains, numbers of Perdiz points (but with other types also common, especially Scallorn), and other traits as detailed by Hester and Hill (1975). 
It has seemed that just when a rather comprehensive view of these Late Prehistoric manifestations is beginning to emerge, new data are obtained which further muddle these concepts. A case in point is the survey and testing work of Nunley $(1975,1976)$ along the Rio Grande in the vicinity of Eagle Pass (roughly 40 miles west of where Hill and Hester have done their research). On the Texas side of the river, Nunley has found evidence of Late Prehistoric occupations (e.g., typical arrow point forms such as Perdiz and Scallorn). Yet, just across the river in Coahuila, his documentation of more than 90 sites has yielded only a few recognizable diagnostic artifacts dating from Late Prehistoric times.

To briefly summarize the present evidence for the Late Prehistoric period in southern Texas, we can discern (1) well-defined cultural units, such as the Brownsville and Rockport Complexes along the coastal strip; (2) gaps in our knowledge and/or the absence of distinctive Late Prehistoric materials in sections of the interior (especially in Starr County and the adjacent areas); (3) a cluster of sites, including Hinojosa, Berclair, 41 ME 19 (near Natalia) and others across the northern and central part of south Texas, with Perdiz points, bone-tempered ceramics, bison (and sometimes antelope) and other fauna--these and similar sites probably represent a new emphasis on bison hunting and an accompanying influx of Plains cultural influence; and (4) Late Prehistoric sites, as on Chaparrosa Ranch and nearby areas, without ceramics or bison, but with distinctive and predictable cultural traits, including Perdiz, Scallorn and Zavala points, tools made on flakes and blades, large end scrapers, and so for.th (see Hester 1974; Montgomery 1977).

ENVIRONMENTAL NOTES

Physiographically, the Hinojosa site and northern Jim Wells County lie within the Rio Grande Plain area of southern Texas (Pool 1975:8). The Geologic Atlas of Texas, Laredo Sheet (Barnes 1976) indicates that the site is buried in alluvium of Recent (Holocene) age; the alluvium is described as "floodplain deposits: clay, silt, sand, gravel and organic matter; silt and clay calcareous, dark gray to dark brown; sand mostly quartz." On either side of the 
site, to the east and west of Chiltipin Creek, the floodplain is flanked by the Lissie Formation of Pleistocene age. To the north and northwest of the site, the Goliad Formation of Pliocene age is exposed (see also Weeks 1933, 1945). According to Barnes (1976) it contains chert nodules in a caliche matrix; exposure of these chert resources might have provided the raw material for chipped stone manufacture at the Hinojosa site.

The northern part of Jim Wells County generally experiences rainfall ranging from 25 to 30 inches annually (Pool 1975:10); the Texas Almanac (1975) lists the average rainfall for the county as 26.70 inches.

The rolling countryside near the Hinojosa site ranges from ca. 235 feet to ca. 370 feet above mean sea level. The site itself lies along the 250-foot contour paralleling Chiltipin Creek (see the USGS San Diego NE 7.5' topographic map). This region is situated well within Blair's (1950:102-105) Tamaulipan Biotic Province, today characterized by a semi-arid climate and thorny brush vegetation. Pool (1975:11-13) includes the area in the "Rio Grande Plain Timbers and Brush" vegetational zone, with the principal trees being mesquite, live oak, post oak and a variety of thorny shrubs. However, early Spanish and Anglo-American documents make it rather clear that the brush infestation present in the area today is a relatively recent phenomenon (cf. Inglis 1964; Hester 1975a).. Hester (1975a:108) attributes the spread of the mesquite forests to several factors: ". . the commercial livestock industry (which led to overgrazing and the increased dispersal of mesquite seeds), short-term climatic changes, and the suppression of (aboriginal) grassfires." Inglis (1964:35) reports that when Benjamin Lundy crossed northern Jim Wells County in 1833, the country was "delightful," "abounding with excellent grass," with timber along the streams and "scarce a bush" in the upland regions. In 1849, a traveler named Michler crossed the northern part of the county, describing it as "high rolling prairie" (ibid.:36). Although the evidence is still inconclusive, it appears that mesquite and chaparral were beginning to be the dominant vegetation forms in the county by the mid-1880s.- Similar mesquite brush "invasions" in southern Texas are described by Price and Gunter (1943), Bogusch (1952) and Inglis (1964). 
Animal life in the site area has also been altered in recent centuries. Today's fauna are typical of those described by Blair (1950) for the Tamaulipan Biotic Province. However, several species of animals once present in the area are now gone, including bison, wolf and pronghorn. Two common species in the vicinity, armadillo and javelina (peccary) are comparatively recent intruders. There is no archaeological record of javelina in other Late Prehistoric or Protohistoric sites in southern Texas (cf. Hester 1975a; Hester and Hill 1975); in fact, as far as the author knows, the earliest archaeological evidence of javelina in the south Texas-extreme northeast Mexico area comes from the Spanish missions at Guerrero (report in preparation at UTSA), dating to the middle part of the 18th century. Armadillo came into the area even later; they were noted in the San Antonio area in the middle to late 19 th century (Anne A. Fox, personal communication). It would appear that this animal was not common in south Texas until the early part of the 20th century (cf. Price and Gunter 1943:14).

\section{SITE DESCRIPTION}

Archaeological site 41 JW 8 (the Hinojosa site) lies on the west bank of Chiltipin Creek in northern Jim Wells County, approximately nine miles northwest of the city of Alice (Figs. 1-3). The creek is deeply entrenched in the site vicinity, with walls $15-20$ feet $(4.5$ to $6 \mathrm{~m})$ high. The riparian vegetation along the stream is dense, characterized by thorny brush and vines. Site deposits are buried in alluvium extending west from the creek bank into a cultivated field. A barbed wire fence, running roughly northwest-southeast, serves to bisect the site. The southern and western sections of the site, 1ying in the field, have been disturbed to a certain extent by plowing. Those deposits along the stream bank and adjacent to the fence are undisturbed.

Cultural materials are generally confined to the upper $30-40 \mathrm{~cm}$ of the sandy loam alluvium (occasional artifacts were found buried as deep as $45 \mathrm{~cm}$ in some parts of the site). Most of the occupational debris is, however, confined to the upper $15-30 \mathrm{~cm}$. Horizontally, the site is at least $80 \mathrm{~m}$ long (northwest to southeast) and approximately $30-40 \mathrm{~m}$ wide (northeast to southwest). Thus, the estimated area of occupation is ca. $3000 \mathrm{~m}^{2}$. 


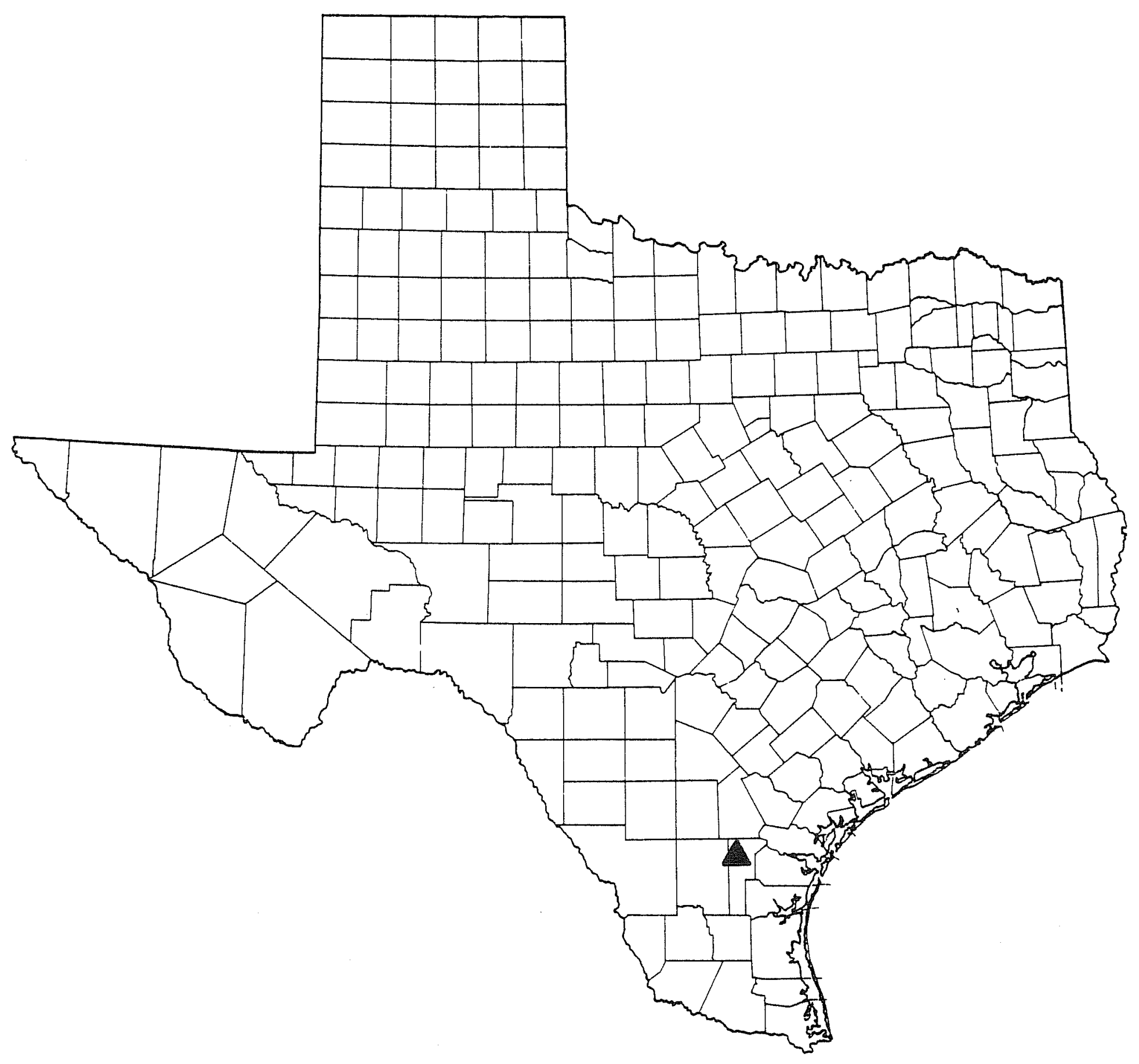

Figure 1. The Location of Site $41 \mathrm{~J}(1) 8$ (Hinojosa), Southern Texas. 
The mean elevation above sea level in the Hinojosa site area ranges from 235 feet to 250 feet. In relationship to the proposed SCS floodwater retarding structure, the site lies well outside the actual construction area. However, it is situated within the detention pool and borders on the 50-year sediment pool.

A stepped, vertical cut placed on the west bank of Chiltipin Creek provided the following information on the subsurface geological structure in the site vicinity. The top 30-40 cm consisted of midden debris buried in browngray, organic-stained alluvium; roots from riparian vegetation were numerous. This same brown-gray alluvium continued to a depth of $195 \mathrm{~cm}$ below the surface of the creek bank. A white-tan clay stratum (culturally sterile) was found from $195 \mathrm{~cm}$ to $260 \mathrm{~cm}$ below surface. At $260 \mathrm{~cm}$, a clay formation with soft caliche inclusions was noted, extending to $340 \mathrm{~cm}$. From 340 to $560 \mathrm{~cm}$ (the level of the creek bed) there was a mottled clay and caliche formation (reworked?). The clay is coarse in texture, with brown mottling. As the depth below the surface increased, particularly around $490 \mathrm{~cm}$, the caliche inclusions were very hard, almost rock-like. Excavations at the site were to reveal, as documented later in this report, hearths and hearthstones made of these hard caliche nodules, apparently picked up or quarried for use as hearthstones by the prehistoric inhabitants of the site.

The visual impression that one obtains from walking across the site, particularly in the open, partly cultivated area west and south of the fence (see Fig. 2), is of abundant cultural remains. The exposed materials include land snails, occasional bits of mussel shell, burned caliche nodules, chert flakes, animal bone fragments, pottery sherds, and lithic artifacts. By scraping the surface with a trowel, charcoal-stained earth and pieces of wood charcoal are also observed.

\section{INVESTIGATION PROCEDURES}

Archaeological investigations at the Hinojosa site involved site mapping, intensive surface collecting (particularly in the plowed field where extensive remains were exposed), and test excavations. A datum point (with an assumed 


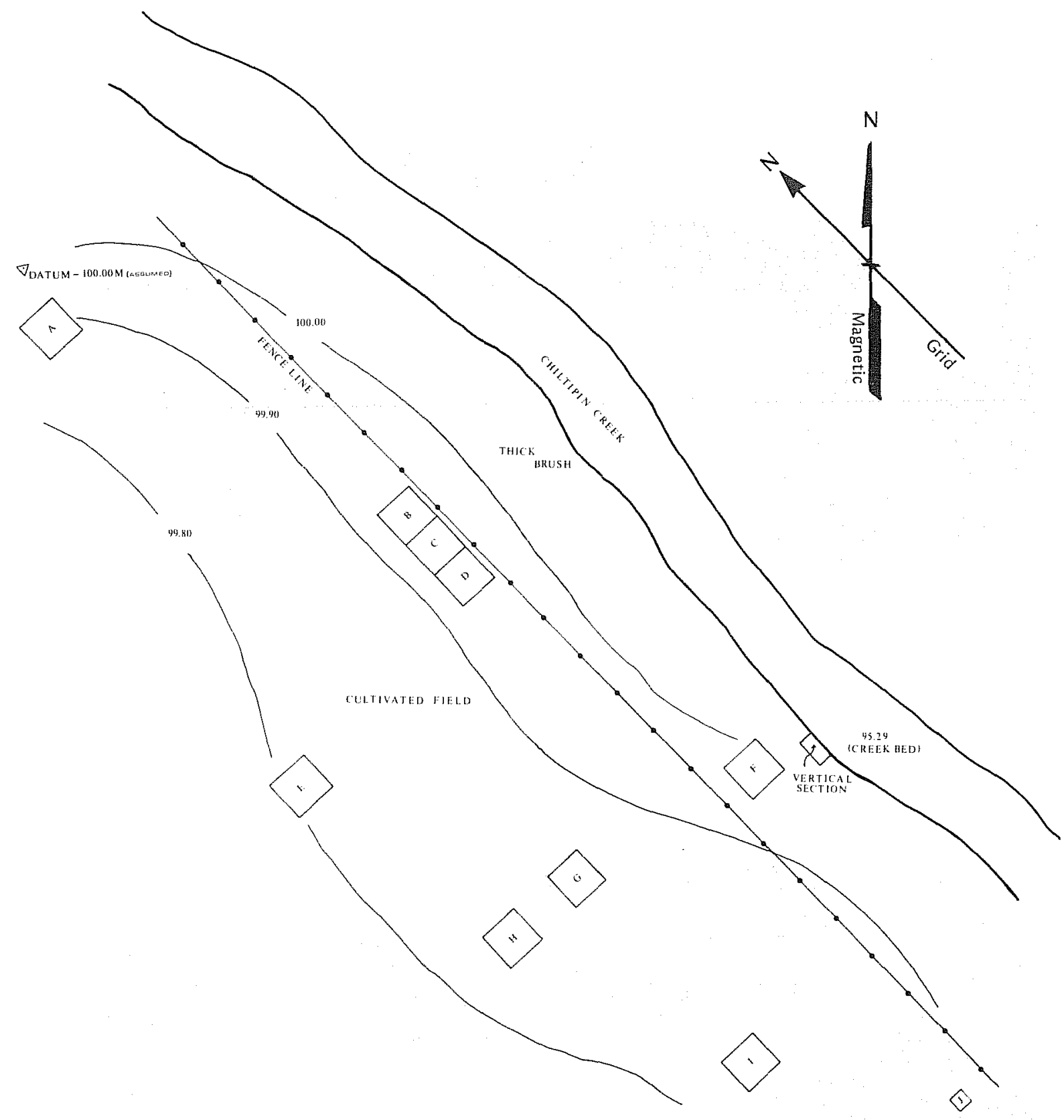

TEST EXCAVATIONS AT
41 JW 8
1475

Figure 2. Map of Site $41 \mathrm{JW} 8$ (Hinojosa). The map indicates the location of test pits excavated at the site in 1975. Contour intervals are $10 \mathrm{~cm}$. Magnetic north and grid north are indicated. 




a

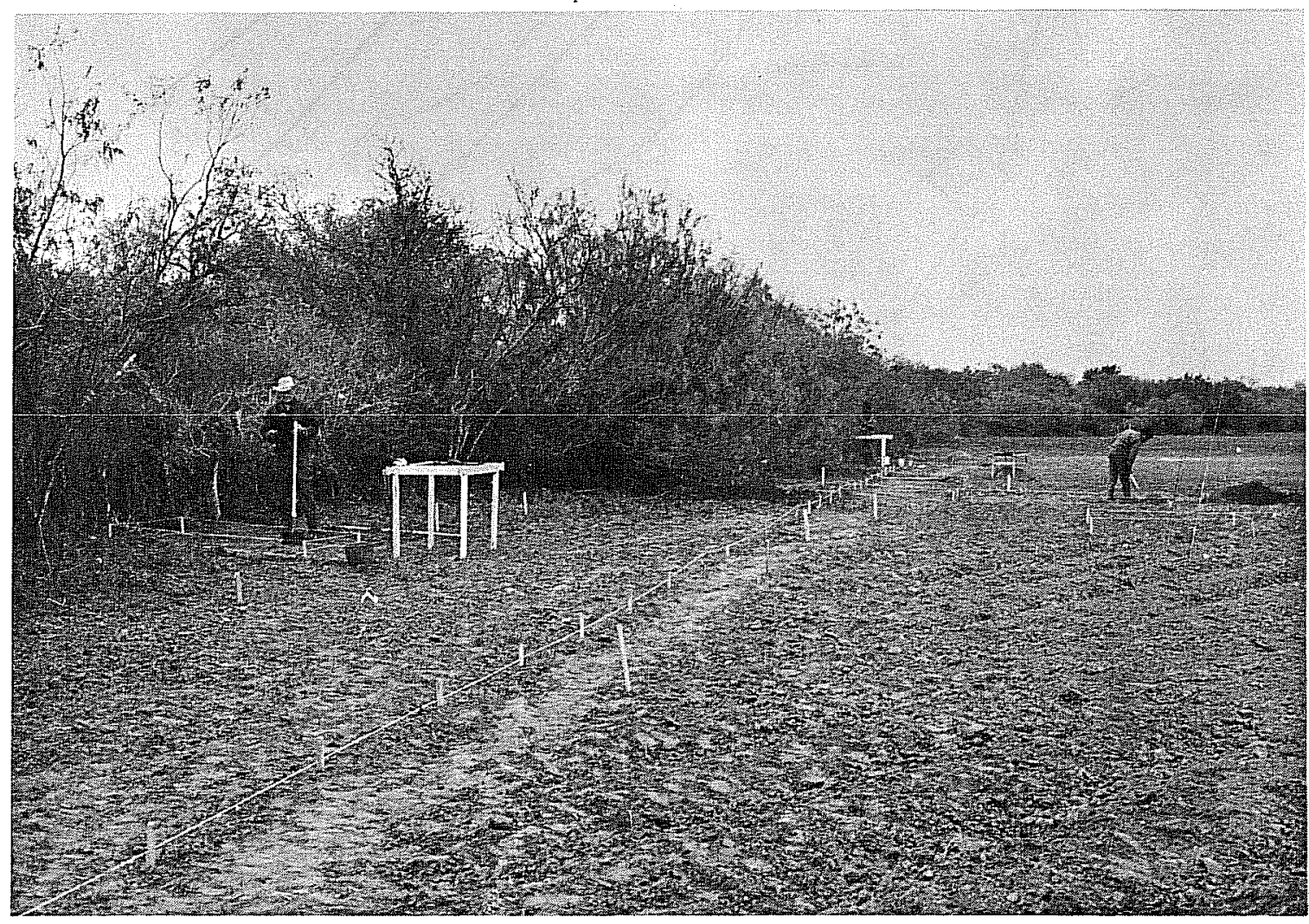

b

Figure 3. Views of Site $41 \mathrm{JW} 8$ (Hinojosa). a, view looking northwest across cultivated field toward central part of site (in background). Note plane table mapping station at left; $b$, view of site looking southeast along the fence line; north-south base line is shown. 
elevation of $100 \mathrm{~m}$ ) was established in the northwest corner of the site (see Fig. 2). From this point, a site base line (designated Grid North, and oriented roughly northwest to southeast paralleling the long axis of the site) was extended $70 \mathrm{~m}$ to the southeast. All excavation units ( $2 \times 2$ meter squares, with the exception of Unit $J$ and the vertical section; see Fig. 2) were assigned grid coordinates (in terms of Grid North layout), using the southeast corner stake as the unit datum. For the sake of convenience, the field coordinates used in designating the units have been replaced with alphabetical designations in this report (see Table 1). The initial test excavations revealed unstratified deposits, and thus arbitrary $15-\mathrm{cm}$ vertical levels were used during the excavations.

As noted earlier, the bulk of the cultural material was found in the upper $15 \mathrm{~cm}$, both in the plow zone of the cultivated field and in the undisturbed areas (such as Units B, C, D and F). In most units, considerable archaeologica1 material continued into the $15-30 \mathrm{~cm}$ level. Scattered flakes and debris were occasionally found to a depth of $45 \mathrm{~cm}$. In the corners of several units (e.g., Unit B) testing was carried down to $100 \mathrm{~cm}$, into a clay loam stratum containing occasional cultural material. Snail shells were often noted. In Unit B there was a scattering of burned rock and flakes at $75-95 \mathrm{~cm}$. In one unit tested to the 100-cm depth, a black gumbo-like soil was encountered.

In summary, the major occupational component was confined to the upper $30 \mathrm{~cm}$ of alluvium. Some materials and features perhaps linked to this component did extend to depths of ca. $45 \mathrm{~cm}$ in certain parts of the site.

All excavated materials were passed through 1/4-inch hardware cloth and a sizable portion was screened through 1/8-inch mesh to maximize faunal recovery. With the exception of burned rock and caliche nodules, all culturally-related debris was saved. Charcoal samples were obtained for radiocarbon analysis, and palynological samples were collected.

In total, 12 units and a vertical section were excavated. Upon completion of the field work, all units were back-filled. Field notes, maps, blackand-white photographs, color transparencies, and all archaeological materials are housed at the Center for Archaeological Research, The University of Texas at San Antonio. 
In addition to the test excavations just described, a plane table map of the site was made (Fig. 2). While the mapping and testing were in progress, an intensive surface collection was carried out.

TABLE 1

GRID COORDINATES FOR EXCAVATED TEST PITS

AT SITE 41 JW 8 (HINOJOSA)

Unit Designation (see Figure 2)

A

B

C

D

E

F

G

$\mathrm{H}$

I

$\mathrm{J}$

$\mathrm{K}$

L
Grid Coordinates

(at SE corner stake)

S4

$\mathrm{S} 22 / \mathrm{E} 6$

$\mathrm{S} 24 / \mathrm{E} 6$

$\mathrm{S} 26 / \mathrm{E} 6$

$\mathrm{S} 28 / \mathrm{W} 12$

S42/E8

$\mathrm{S} 40$

S40/W4

$\mathrm{S} 52$

$\mathrm{S} 60 / \mathrm{E} 6$

S70

S70/E2 
INTRASITE FEATURES

The test excavations revealed several specific features, or activity areas, which are described below.

Hearths. Clusters of burned stone or caliche nodules interpreted as hearths or cooking areas were found at the site. In Unit B, at $75-95 \mathrm{~cm}$ in the northeast quadrant, there was a scatter of burned rock, perhaps representing the disturbed remnants of an earlier occupation at the site. Flakes, flecks of charcoal, and bone fragments occurred in apparent association with this burned rock scatter. A somewhat similar burned rock scatter, although more concentrated, occurred at a depth of $16 \mathrm{~cm}$ in the northwest quadrant of Unit $H$. There were no associated materials. In Unit $L$, a burned rock cluster (again, with no definable shape) was found in the northeast quadrant in the 0-15 cm leve1. A disturbed hearth was found in the same unit in the $15-30 \mathrm{~cm}$ level, apparently associated with a bone concentration which is described below. A Perdiz point and bone fragments may have been associated with this burned rock feature.

In Unit L, a well-defined hearth was cleared at a depth of 52 to $56 \mathrm{~cm}$. The depth of the feature may be attributed to an erosional cut in this section of the site, an area into which animal bone refuse had been thrown (see below). The hearth is illustrated in Fig. 4,a,b. The top of the burned rock concentration was noted at $52 \mathrm{~cm}$, and it extended to a depth of $56 \mathrm{~cm}$. The diameter of the main rock cluster was ca. $30 \mathrm{~cm}$, but as can be seen in Fig. 4, some of the hearthstones had been scattered to the north of the main concentration. Flecks of charcoal were noted around the hearth; a Rabdotus snail and fragments of small mussel shells were found within the cluster of burned rock.

Bone concentration. Excavations in Units $K$ and $L$ at the south end of the site revealed a veritable "bone bed." This concentration consisted largely of bison bone (in fact, the bulk of bison remains came from this area), but included several other species of animals (see Table 2; these other animals included frogs, turtles, snakes, birds--one perhaps a vulture, a variety of sma11 mammals, deer and pronghorn). Snails and mussel shells were also scattered throughout the bone concentration. 


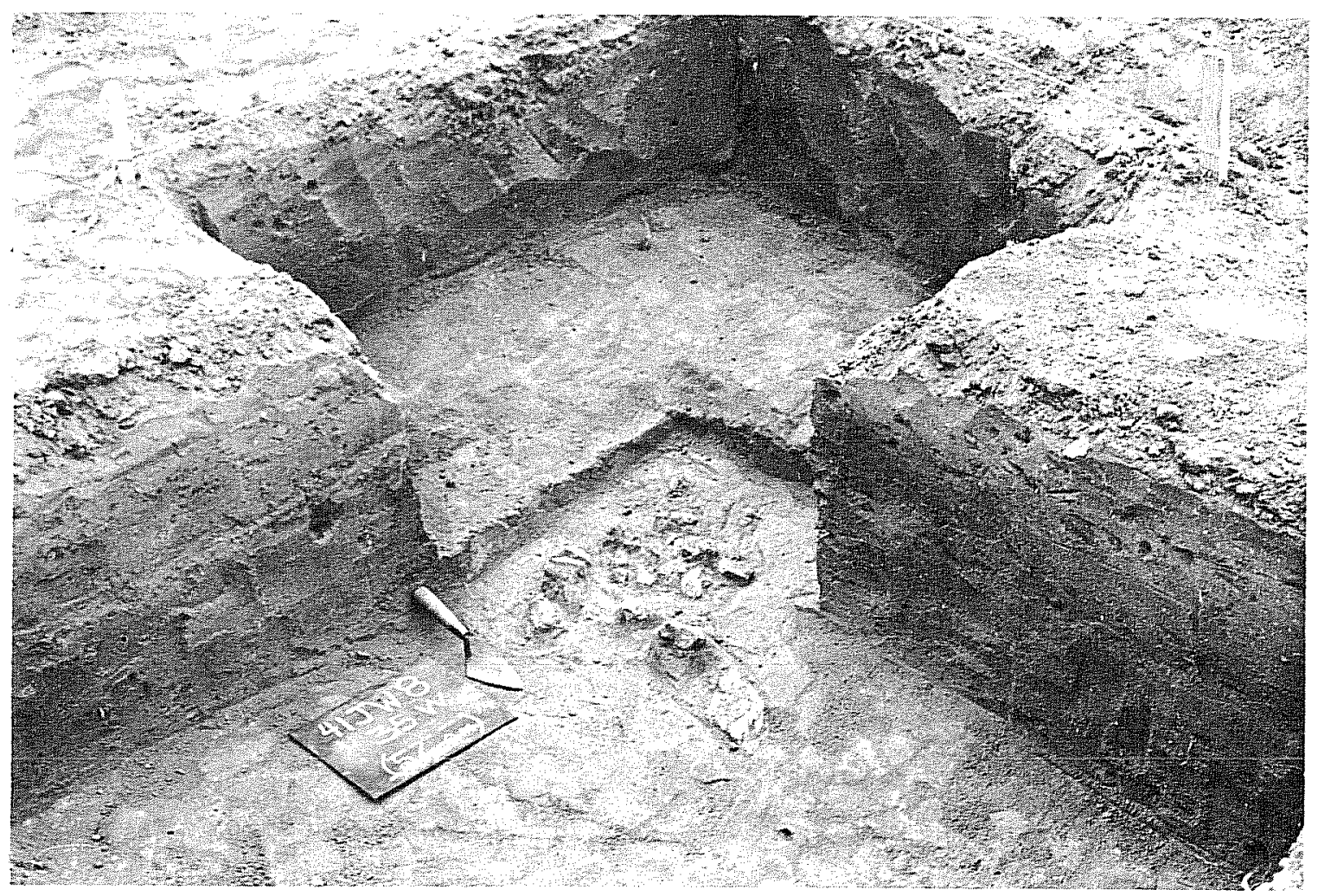

a

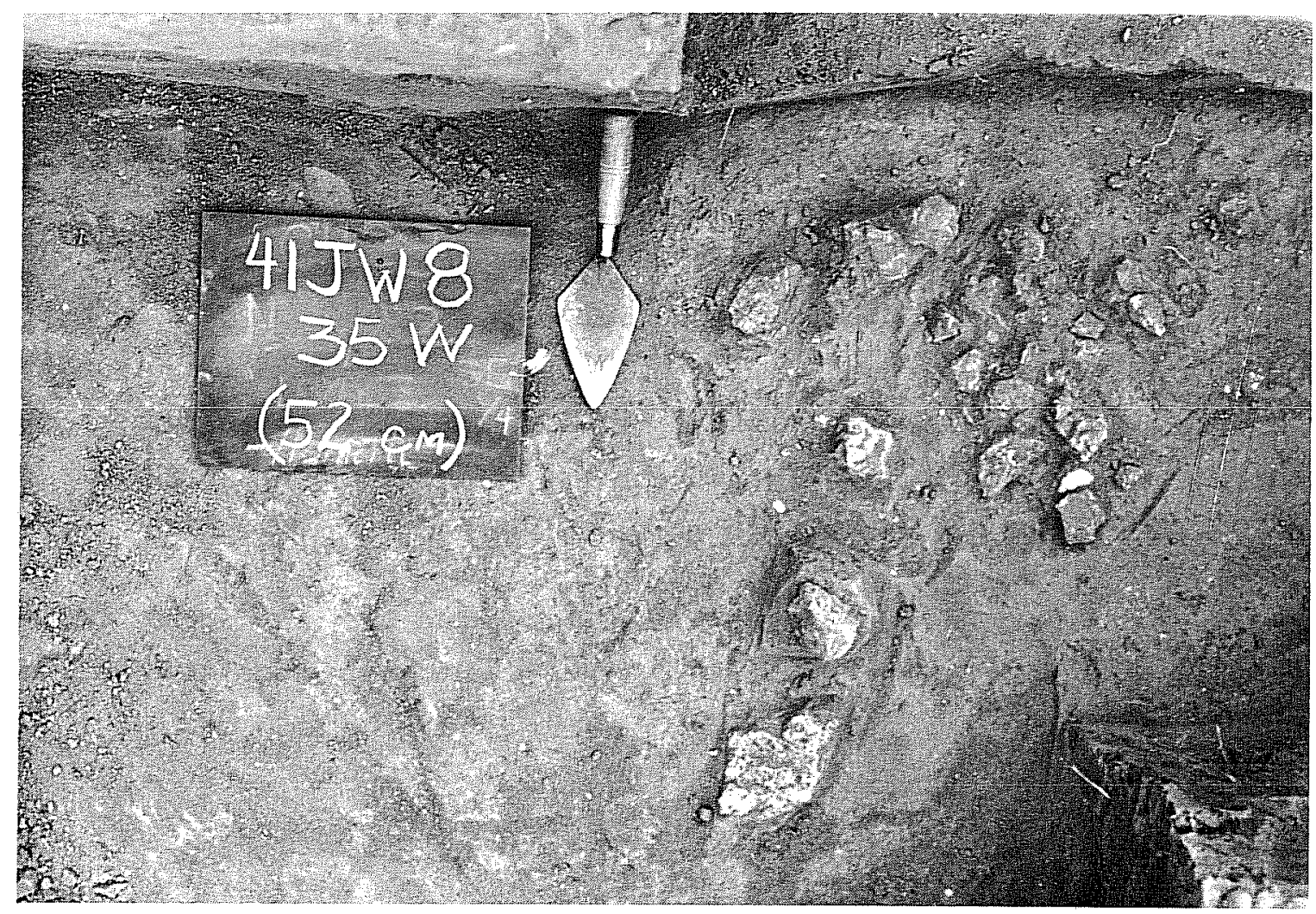

b

Figure 4. Views of Hearth at Site $41 \mathrm{JW} 8$ (Hinojosa). a,b, two views of hearth in Unit $\mathrm{K}$; trowel points north. 
The concentration began at about $28-30 \mathrm{~cm}$ below the surface and continued to a depth of $56 \mathrm{~cm}$. North-south profiles indicate that the bones had been placed (discarded?) in an erosional cut, perhaps a gully. Time did not permit the full horizontal exploration of this very interesting feature. We suggest, however, that it was a gully, running southwest-northeast toward the creek, into which butchered animal bones and other camp refuse were thrown. There were, however, some clusters of bones within the area, and it is possible that some of the actual butchering tasks took place here. As mentioned above the horizontal limits of the concentration are not known, although it was more than one meter in width.

Other refuse, in addition to animal bone, included burned rocks, snails, mussel shells, mussel shell fragments, Perdiz arrow points, tiny end scrapers and potsherds. In Unit $\mathrm{K}$, at a depth of 28 to $32 \mathrm{~cm}$ in the southwest quadrant, the excavators uncovered a stack of five bison ribs. In Unit L, clusters of large articular ends of bison long bones were found in the $30-45 \mathrm{~cm} 1$ level.

\section{THE ARTIFACTS}

Artifacts recovered during the 1975 intensive survey program at the Hinojosa site are described in this section. For a description of those materials found in the initial site survey, see Hester and Bass (1974).

The artifact descriptions presented here are designed with a minimum of verbiage. Thus, incomplete sentences are occasionally used, along with the following abbreviations: L: length; $\mathrm{W}$ : maximum width; $\mathrm{T}$ : maximum thickness; Wt: weight in grams. Linear measurements are in miliimeters.

\section{Arrow Points}

\section{Perdiz (31 specimens; Fig. 5,a-a')}

The Perdiz arrow point type was the only projectile point form represented in the entire lithic assemblage at the Hinojosa site. This is an unusual archaeological phenomenon in southern Texas (cf. Hester and Parker 1970), since at most sites a variety of arrow point forms usually occur (e.g., the sites reported by Hester and Hill 1975). The fact that only Perdiz. points are found at Hinojosa would seem to suggest a single cultural component, although it is obvious that one 


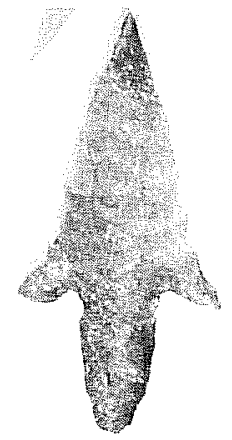

a

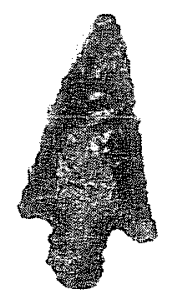

9

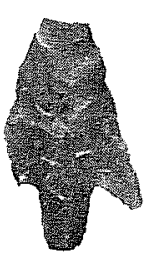

m

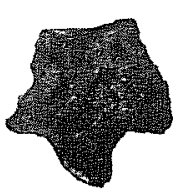

5



Y

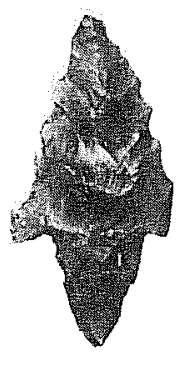

b



h

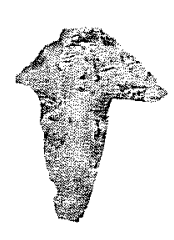

抟
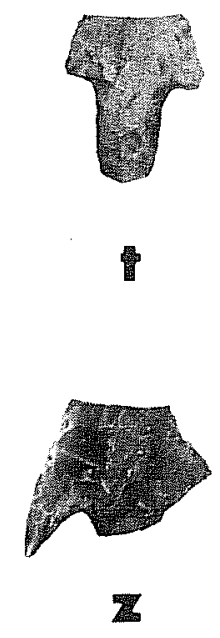


c

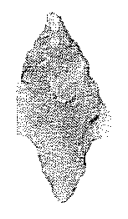

i



0
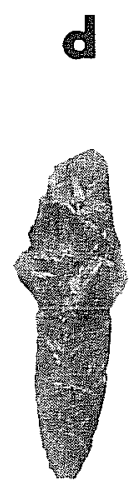

j



k
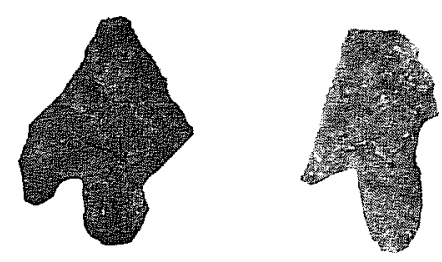

9
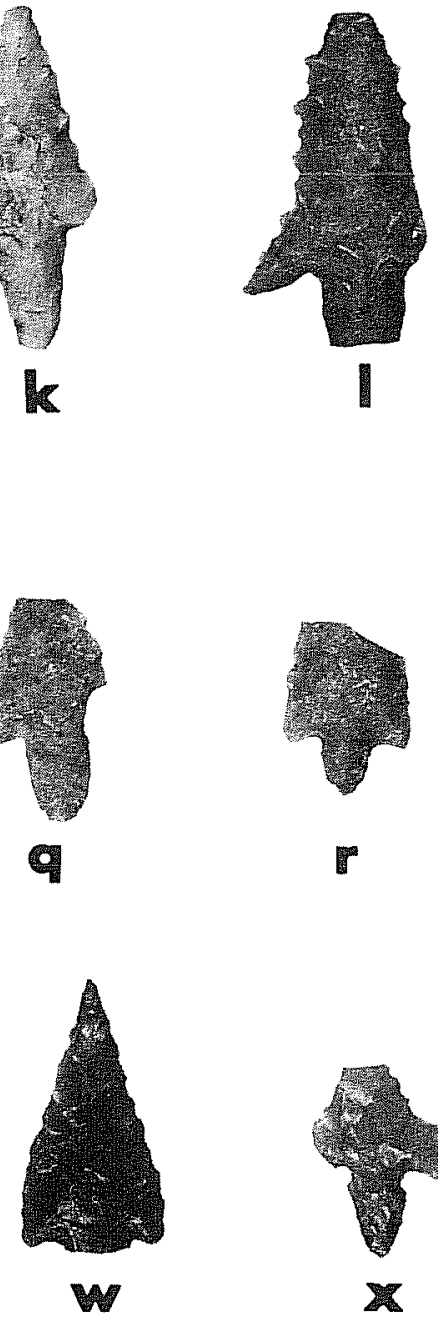

P

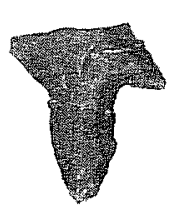

u



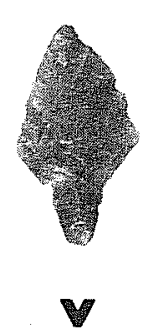

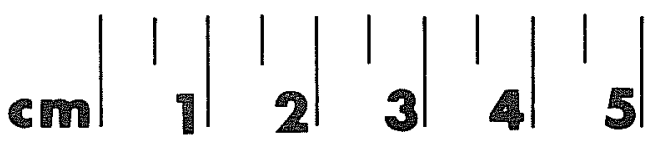

Figure 5. Arrow Points from Site $41 \mathrm{~J}(\omega) 8$ (Hinojosa). a-a', Perdiz. 
cannot tell if it was a one-time occupation, or a series of occupations over what was perhaps a fairly brief time span (see Chronometric Analysis section).

Specimens show wide variation in morphology, material and technology. Both bifacial or partly bifacial and unifacial flaking were used in manufacture. Specimens range from large examples $39 \mathrm{~mm}$ in length to tiny, mostly unifacial points $18 \mathrm{~mm}$ in length. Of the 21 specimens, nine are essentially complete. One specimen appears to be a preform broken during the final shaping of the stem. L: 18-39; W: 7.7-19.3; T: 1.9-3.5; Wt: 0.4-1.2.

\section{Bifaces}

Four-beveled knives (2 specimens; Fig. 6,a,b)

Both are fragments of alternately-beveled bifaces, usually referred to as "Plains knives," often found with Perdiz and ceramic assemblages in southern Texas (cf. Hester and Hill 1975). One specimen is made of gray quartzitic chert and is alternately beveled on left edges; there is some dulling resulting from wear on one edge. The other is a small tip fragment, also alternately beveled on left edges, but made of gray-brown fine-grained chert; heavily dulled on both edges. L: $30.4,15.9 ;$ W: $12.9,13.6 ;$ T: 6.4,2.3; Wt: 2.6,0.4.

\section{Crude bifaces ( 8 specimens; Fig. 7,a-f)}

These are mostly ovate bifaces, crudely worked. Most appear to be preforms aborted during the reduction process. One specimen is an apparent Perdiz preform which could not be thinned because of repeated hinge flakes at the proximal end on both faces. Another rectangular biface has a knot or "hump" on one face that precluded further thinning.

Three specimens are thinner than the others and may have functioned as knives. Two specimens in the category are burned. L: 25.8-43.7; W: 14.9-41.5; $\mathrm{T}: 5.4-16.7$; Wt: $5.8-14.7$.

Miscellaneous biface fragments (2 specimens; not illustrated)

One may be the distal tip of a drill, and the other is probably the tip of a preform. 

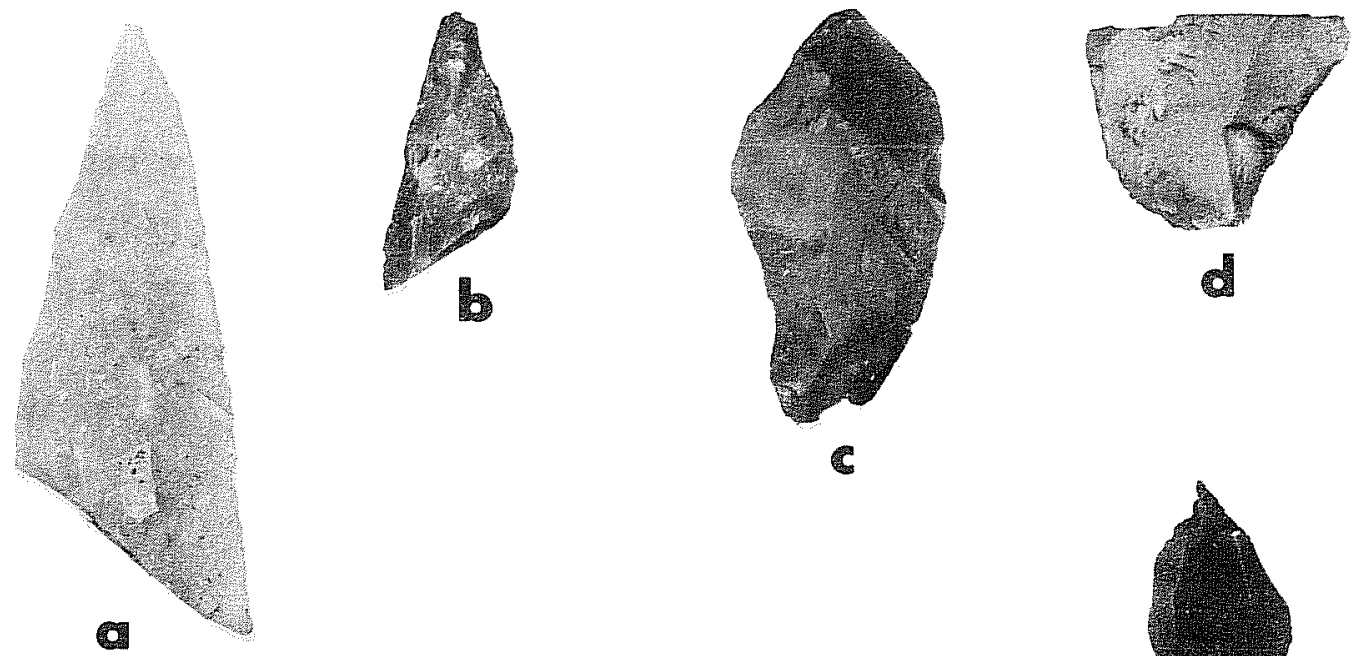

\begin{tabular}{l|l|l|l|l|l|}
1 & 1 & 1 & 1 & 1 \\
\hline c I I & 2 & 3 & 4 &
\end{tabular}

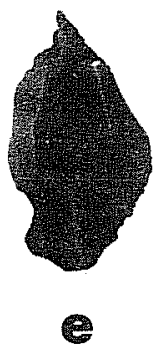

Figure 6. Lithic Artifacts from Site $41 \mathrm{JW} 8$ (Hinojosa). a,b, fragments of four-beveled knives; c,d, trimmed flakes; e, graver. 

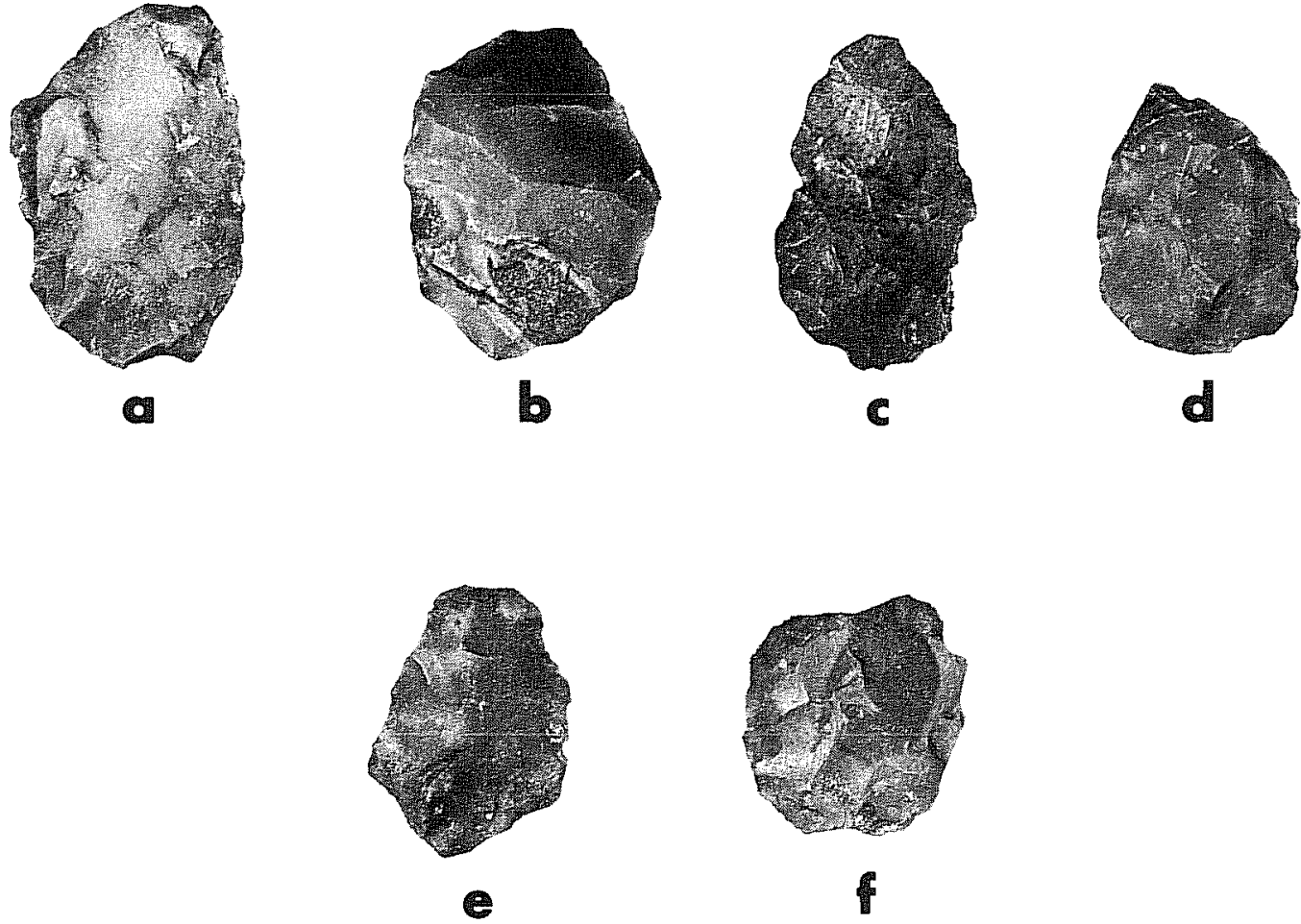



9
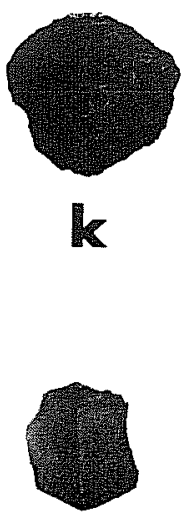

6

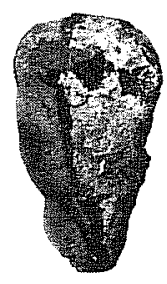

h

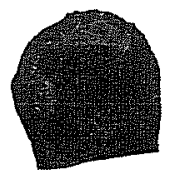

I

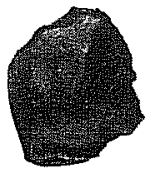

IT

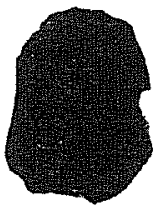

j

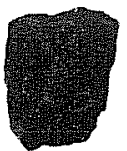

T

Figure 7. Lithic and Shell Artifacts from Site $41 \mathrm{JW} 8$ (Hinojosa). $\mathrm{a}-\mathrm{f}$, crude bifaces; g-o, end scrapers; $\mathrm{p}$, fragmentary conch shell disc bead; $q$, section of Dinocardium. 


\section{Unifaces}

End scrapers ( 9 specimens; Fig. 7,g-o)

As reported by Hester and Bass (1974), one of the main 1ithic traits at the site is the tiny unifacial end scraper. Given the small size of the specimens, they must have been hafted for use, either on 1ong, straight hafts as reported from Coahuila by Hester (1971a), or more likely, on L-shaped antler scraper handles as found on the Great Plains (cf. Metcalf 1970:Figs. 1 and 2) or in curved antler tine hafts as found in the Central Plains (cf. Wedel 1970: Figs. 1 and 2).

Two of the specimens are made on lipped (biface thinning?) flakes, five are made on interior flakes, one on a secondary cortex flake, and one on the medial section of a blade (trimmed steeply at both ends). One specimen has been slightly burned.

Because these tiny end scrapers have not been previously documented in detail from southern Texas, dimensions and edge angle measurements (of the bit ends) are listed below:

$\begin{array}{lcrcc}\text { L } & \underline{W} & \underline{T} & \text { Wt } & \text { Edge Angle } \\ 35.6 & 24.0 & 9.0 & 4.3 & 51^{\circ} \\ 23.9 & 17.7 & 5.9 & 3.3 & 67^{\circ} \\ 31.5 & 18.0 & 15.0 & * & 57^{\circ} \\ 19.0 & 18.5 & 3.7 & 1.6 & 54^{\circ} \\ 25.0 & 20.0 & 5.7 & 2.5 & 32^{\circ} \\ 20.3 & 16.6 & 3.4 & 1.4 & 53^{\circ} \\ 26.4 & 19.5 & 5.6 & 2.8 & 64^{\circ} \\ 17.0 & 14.0 & 5.0 & * & 81^{\circ} \\ 15.0 * * & 12.0 & 3.0 & * & 66^{\circ}\end{array}$

* Weights not available

** Specimen made on a medial blade fragment

Graver (1 specimen; Fig. 6,e)

Made on an interior flake. Unifacially chipped inset forming graver-like tip on one edge. Tip is quite sharp with no obvious signs of wear. L: 28; W: 15; T: 4; Wt: not available. 


\section{Trimmed flakes ( 4 specimens; Fig. 6,c,d)}

Three are fragments of flakes. Of the four, two are trimmed along one edge, one is trimmed on two edges. The fourth has minor ventral trimming on one edge, and is bifacially trimmed at the distal end; possible preform.

Cores ( 7 specimens; Fig. 8,a-g)

The cores are mostly small, made on small nodules of local gravels, perhaps obtained from outcrops of the Goliad Formation to the west and northwest of the site. No special preference for a particular kind of chert is reflected by the core sample.

Brief descriptions appear below:

1) Multifaceted platform, 34 × $20 \mathrm{~mm}$; made on $1 / 4$ of a small pebble; three flakes removed from one face; one of these is blade-1ike. Core height: $36 \mathrm{~mm}$; maximum diameter: $43 \mathrm{~mm}$; fine gray chert.

2) Bifacially reduced ovate core; probably exhausted. Random flake removal pattern. Thickness: $23 \mathrm{~mm}$; maximum diameter: $43 \mathrm{~mm}$; coarse dark gray chert.

3) Made on halved pebble; chopper-like, i.e., bifacially reduced from acute edge (edge angle, $31^{\circ}$ ). Core height: $37 \mathrm{~mm}$; brown-gray chert.

4) Halved nodule with three separate platforms; two are multifaceted, one is covered with cortex. Platforms seem to have been changed when hinge flakes occurred. Core height: $33 \mathrm{~mm}$; maximum diameter: $36 \mathrm{~mm}$; brown-gray fine-grained chert.

5) Halved pebble, with single-facet platform created by splitting of the pebble. Series of small flakes and blades removed. Platform is $26 \mathrm{x}$ $31 \mathrm{~mm}$; core height: $26 \mathrm{~mm}$; maximum diameter: $31 \mathrm{~mm}$; white, fine-grained chert.

6) Pebble core with three platforms; one is flat cortex surface at one end with single facet platforms on either side on edges of pebble. 


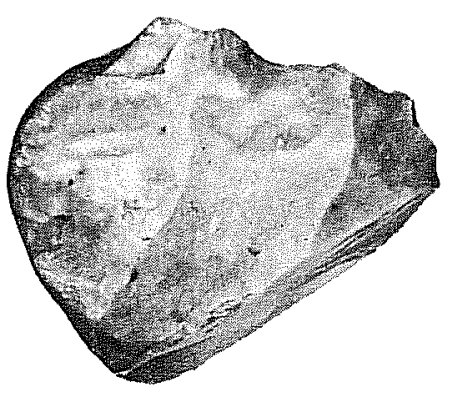

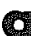
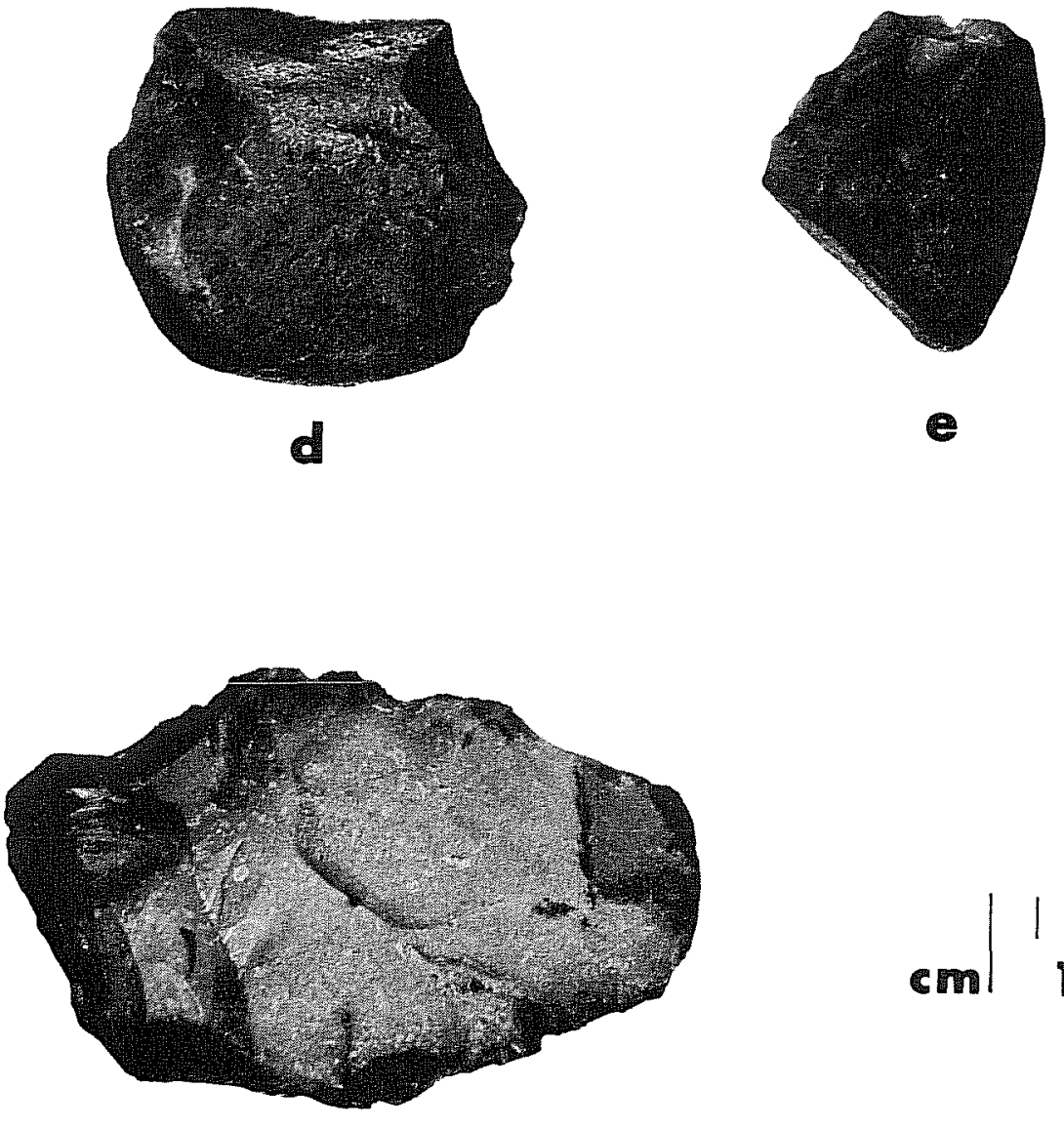

e

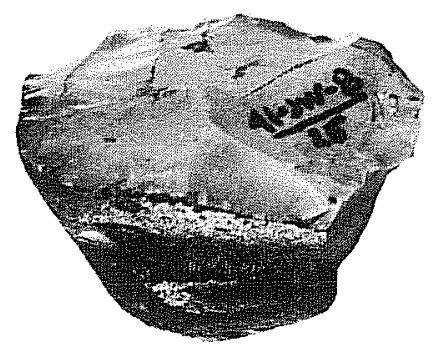

b

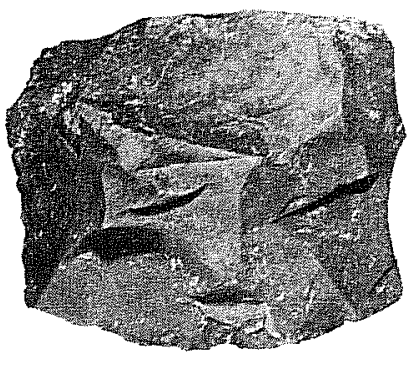

C

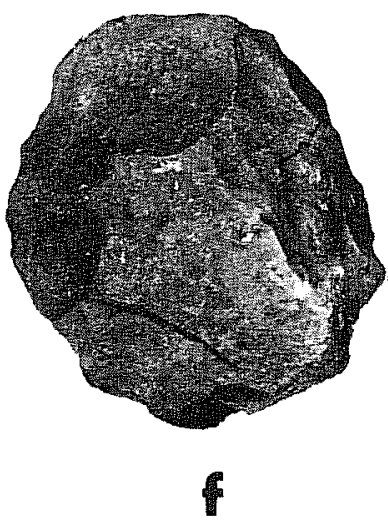

Figure 8. Lithic Artifacts from Site $41 \mathrm{JW} 8$ (Hinojosa). a-g, cores. 
Single facet platforms seem to be secondary to the cortex platform. Hinge flakes ruined all three platforms. Core height: $39 \mathrm{~mm}$; maximum diameter: $28 \mathrm{~mm}$; tan-1ight brown chert.

7) Largest core of sample; made on halved elongate cobble. Unifacially and randomly flaked from edges. May actually be an early stage in biface production. Core height: $25 \mathrm{~mm}$; maximum diameter: $71 \mathrm{~mm}$; gray-brown fine-grained chert.

Flakes

A total of 1013 flakes and flake fragments were recovered at the Hinojosa site. Since 1/4-inch mesh screen was used at times, it is to be expected that a number of very tiny flakes and flake fragments were not collected.

A cursory analysis of the flakes was carried out, and they were sorted into several major categories, following the definitions of Hester (1971b). These categories reflect the lithic reduction process, from the initial shaping of a core to the thinning of a biface.

Twenty-two primary cortex flakes were counted. There were 77 secondary cortex flakes and 69 interior flakes. Biface thinning flakes ("1ipped flakes") accounted for 124 specimens. There were 719 fragmentary flakes, either tiny chips, or lacking sufficient attributes to allow their placement in any of the above categories. Two distinctive blades were recognized (blades and implements made on blades occur in the Late Prehistoric in south and lower coastal Texas; see Hester and Hill 1975; Hester and Shafer 1975).

If one disregards the flake fragments, there are 294 classifiable flakes from the site. The various categories are represented by the following percentages: primary cortex, $7 \%$; secondary cortex, $26 \%$; interior, $24 \%$; biface thinning, $42 \%$; blades, $1 \%$. These percentages would indicate that decortication of cores and/or initial stages of biface reduction took place. elsewhere--perhaps at special quarry-workshops at exposures in the Goliad Formation. Such activityspecific sites, as reflected by flake studies, have been reported by Hester $(1975 b)$ in the northwest sector of southern Texas. It would appear that the 
major aspect of the lithic technology at Hinojosa was directed toward bifacial reduction, probably the manufacture of Perdiz points and knives. Some of the so-called biface thinning flakes have dulled striking platforms, perhaps from abrasion of the edge prior to thinning or perhaps representing the removal of a dulled knife edge.

The heaviest concentrations of flakes were noted in Units $C, D, H$, I and $\mathrm{K}$ (the latter being the area of the bone concentration).

Although the debitage at many Late Prehistoric sites in southern Texas has not been adequately studied, one has the impression that blade production was more common than seen at Hinojosa (cf. Hester and Shafer 1975). Perhaps many of the blades produced at Hinojosa (as indicated by blade facets on some of the cores) were used in making Perdiz arrow points and end scrapers. However, the long, trimmed blades found on the lower coast (ibid.) and at the Late Prehistoric Berclair site in Goliad County (Hester and Parker 1970) are absent in the Hinojosa assemblage. The varying lithic assemblages of Late Prehistoric and Protohistoric sites in the southern half of Texas are still inadequately known, and it can only be hoped that further research will clarify the situation.

Ceramics (Fig. 9,a-h)

A total of 122 potsherds were found in surface and excavated contexts at Hinojosa. The sherds fit, for the most part, into the bone-tempered plainware tradition reported for southern Texas by Hester and Hill (1971). This ceramic tradition is very similar to, and perhaps is derived from, the Leon Plain ceramic tradition of the Toyah Phase of central Texas. Several other potsherds were found in the 1974 survey and are illustrated by Hester and Bass (1974:Fig. 2, m-o).

Anne A. Fox (Research Associate of the Center) and T. R. Hester have examined the 1975 ceramic sample from the site. The vast majority of the sherds (97 or $80 \%$ ) fall into the bone-tempered plainware category. Most would fit within Hester and Hill's (1975) "Group A." They describe such sherds (Hester and Hill 1975:197) as having hard and compact pastes, and bone tempering (with the tempering agents up to $1.0-1.5 \mathrm{~mm}$ ) with both burned and unburned bone present. 




6:

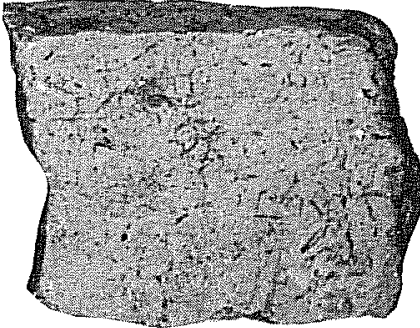

$b$

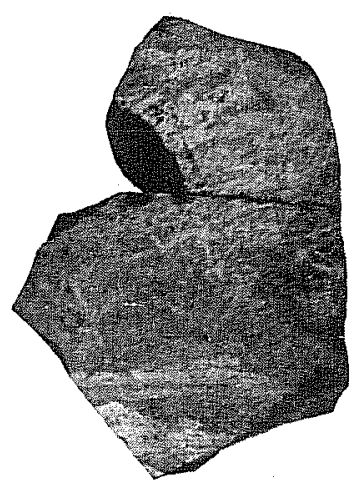

(c)

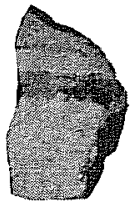

d

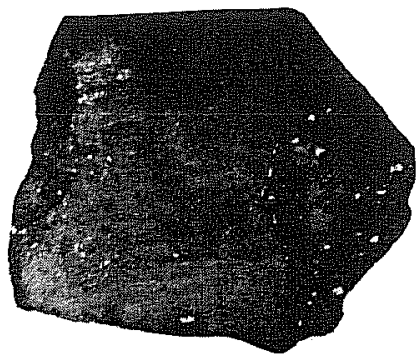

9

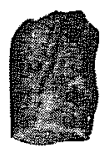

(2)



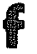

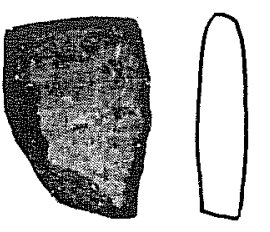

解 h

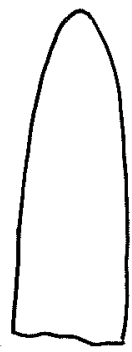

\begin{tabular}{l|l|l|l|l|l|} 
& 1 & 1 & 1 & 1 & 1 \\
cm & 1 & 2 & 3 & 4 & 5
\end{tabular}

Figure 9. Ceramics from Site $41 \mathrm{JW} 8$ (Hinojosa). a-h, potsherds. a, typical example of bone-tempered plainware; b, sherd with worn or ground edge; $c$, sherd from thick vessel, with rough interior and polished exterior; $d$, sherd with asphaltum stripe; e, possible effigy fragment; $f-h$, rim sherds of bone-tempered plainware vessels (rim profiles are shown; exterior surface to the right). 
Cores of the sherds are dark gray, grayish-brown or reddish-yellow (depending on the firing temperatures). Surfaces are usually plain, and the exteriors are often burnished, with bone flecks exposed; interiors are roughly smoothed. Color of the surfaces is highly variable, but includes primarily reddishyellow, light red, very pale brown, and pink. Most sherds of Group A range from 3.0-4.0 on Moh's scale of hardness.

Among the sherds at Hinojosa that would fit within Group A, two have remnants of asphaltum decoration (cf. Hester and Parker 1970). Three rim sherds are present, and Fox believes that they hint at rim diameters of ca. $20 \mathrm{~cm}$. Although no vessel shapes could be reconstructed, we think that most of the vessels were round-bottomed bowls and jars. Burnishing is present on a number of sherds, always on the exterior surfaces.

Fox also noted nine sherds with sandy pastes more typical of the coastal zone, although sandy paste sherds with bone inclusions are found in the interior (Hester and Hill 1971:197). One possible Rockport ware sherd was observed and may represent contacts, probably trade, with coastal Rockport Phase peoples of this same time period. Two sherds were grit-tempered; another sherd appears to have been used as a tool, perhaps as a scraper in pottery manufacture. Additionally, Fox noticed a cylindrical ceramic fragment that could be either a handle or a portion of a figurine. Fox has seen in Spanish mission collections small ceramic figurines of animals with similar paste, temper and color attributes as on the specimen from Hinojosa. However, the artifact is so fragmented that positive identification is presently impossible.

A number of the bone-tempered (Group A) sherds at the site vary somewhat in color from those described by Hester and Hill (1971). Several are almost white (Munsell Hue 2.5YR,8/2), grading to yellow (Hue 2.5YR,8/4).

In summary, there is little difference in the ceramics at the Hinojosa site from ceramic assemblages found at essentially contemporary sites in other parts of southern Texas (Hester and Hill 1971, 1975). There are no sherds of Goliad ware, common at many of the missions in the Spanish Colonial period. The few atypical sherds at Hinojosa may represent either minor variations in the overall ceramic tradition or vessels acquired by trade from other potterymaking peoples. 
Modified Shells (2 specimens: Fig. 7,p,q)

One specimen is a fragmentary conch shell disc bead. It is $1.25 \mathrm{~mm}$ thick. The second specimen is a cut rectangular section of Dinocardium sp. L: 23; $\mathrm{W}: 16 ; \mathrm{T}: 3$.

CHRONOMETRIC ANALYSIS

Two samples of wood charcoal were submitted to The University of Texás at Austin Radiocarbon Laboratory. The following results were obtained (E. Mott Davis and Sam Valastro, personal communication):

Tx-2206. This was a rather small sample of charcoal submitted because of its association with the bone accumulation in Units $K$ and $L$ at the southern end of the site. A radiocarbon assay of $650 \pm 1230$ B.P. was obtained (ca. A.D. 1300). The date falls within the range expected for the Late Prehistoric occupation at the site. However, the small sample size resulted in such a large margin of possible error that it should probably be ignored.

Tx-2207. A large sample of charcoal from Unit $H$ was obtained in Leve1 1 (0-15 cm), associated with Perdiz arrow points and bone-tempered pottery. Chronometric analysis yielded a date of $580 \pm 50$ years B.P. (A.D. 1370). The calibration studies conducted by Ralph, Michael and Han (1973) indicate that no adjustments or corrections are necessary for this date.

Discussion. The date represented by sample $\mathrm{Tx}-2207$ is in line with others obtained from Late Prehistoric sites in southern Texas having somewhat similar assemblages (cf. Hill and Hester 1973; Hester and Hil1 1975).

Charcoal was abundant in the midden and in the bone concentration at the site. However, it occurred mainly as stains, flecks and scattered small fragments. We have some additional samples from the site that might be suitable for analysis, but funds were not available at the time of analysis to permit dating. Any further research effort at the site should make a concerted attempt to secure charcoal samples from good contexts. We feel that several more dates are needed to better define the age of this occupation. 


\section{PALYNOLOGICAL ANALYSIS}

The excellent preservation of bone in the midden at Hinojosa led us to hope that pollen data might be obtained. A series of soil samples were collected for such analysis and in May 1975, one of these (from Unit H, 20-30 $\mathrm{cm}$, collected from below the plow zone) was submitted to Dr. V. M. Bryant, Jr. of the Texas A\&M University Anthropological Research Laboratories.

Dr. Bryant reported (1etter to T. R. Hester, May 14, 1975) that ". . the pollen sample you submitted from Site 41 JW 8 did not contain sufficient pollen to conduct a meaningful analysis. Pollen preservation. . . was very poor and we were only able to recover a few grains (not identified) after analyzing 150 grains of sediment."

Because of the poor results obtained from this one sample, it was decided that no additional samples would be submitted for analysis (these remaining samples are stored in the Archaeology Laboratory at UTSA where they are avai1able, if needed, for future research).

The absence or scarcity of preserved pollen at 41 JW 8 was not totally unexpected. Previous samples had been submitted from Late Prehistoric sites at Chaparrosa Ranch, Zavala County, and there was no preserved pollen (see Hester 1974). More recently, Bryant (in Hester and Kelly 1976:17-19) analyzed soil samples from site $41 \mathrm{ME}$ 19, a Late Prehistoric site in Medina County with a very similar cultural assemblage. Again, pollen grains in significant numbers were absent. Bryant (ibid.:18-19) offered the following discussion regarding the lack of preserved pollen at $41 \mathrm{ME} \mathrm{19;} \mathrm{these} \mathrm{comments} \mathrm{are} \mathrm{reprinted}$ here, as they reflect the general conditions he has encountered in attempting to extract pollen data from other Late Prehistoric sites in southern Texas:

Lack of preserved pollen from these samples could have resulted from any one or a combination of the following causes.

1. The almost total absence of pollen and the presence of at least some fungal spores suggest that some pollen destruction resulted from an attack by fungi. Certain fungi groups rely upon the cytoplasm within pollen grains as their primary source of food. These fungi also have the ability to 
either destroy the pollen wall or weaken it so that other types of mechanical destruction can occur. It is difficult to determine the presence of these fungi in samples prior to actual processing since these fungal types do not occur in all soils nor in all environments.

2. Repeated wetting and drying of the soils would speed the breakdown and oxidation of non-carbonized organic materials, such as pollen. I am unable to determine whether or not this could have acted as one of the causes of pollen destruction in these samples. I suspect that it may have been at least a contributing factor since there was little organic material at all in any of these samples.

3. The presence of small flecks of carbon in one of the samples suggests the repeated use of fires within the site area. This would also tend to speed pollen destruction in those areas immediately under or near hearths.

FAUNAL REMAINS

Over 7000 grams of animal bone, representing 27 species, as well as a number of unidentifiable fish, turtles, snakes and birds, were recovered from the site (see Table 2). The faunal material was identified by Billy Davidson (Austin). Most of the animal bone remains were concentrated in the upper $30 \mathrm{~cm}$ of the deposits, although some materials came from greater depths in the area of the bone concentration.

In the bone concentration in Units $\mathrm{K}$ and $\mathrm{L}, 12$ of the 15 identified bison individuals were found. As noted earlier in the text, several other species were also found in this "bone bed." This seems to have been a gully which may have served as both a bone and rubbish disposal area and as a general faunal processing locus.

The vast majority of the animals represented in the Hinojosa faunal assemblages are present in the area today, with the notable exception of bison, pronghorn and gray wolf. Similarly, no recent faunal intruders, such as armadillo or javelina, are present in the collection.

According to Davis (1974:16), gray wolves were formerly common "in the grassland haunts of the buffalo on which they relied for their chief food supply." Davis (ibid.) notes that they are present today only as rare occurrences in the Trans-Pecos area, into which they cross out of Mexico. 
A SUMMARY OF FAUNAL REMAINS AT SITE 41 JW 8 (HINOJOSA)*

FAUNA

Scientific Name

\section{Ictalurus sp.}

Rana spp.

- $\ldots$

Pseudemys spp.

Terrapene spp.

Natrix spp.

Coluber spp.

Elaphe spp.

Crotalus spp.

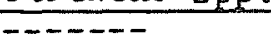

Meleagris

gallopavo

cf. Adura sp.

Geococcyx

californicus

Didelphis

marsupialis

Proycan lotar

Canis cf. latrans

Canis lupus

Mephitis mephitis

citellus spp.

Citellus mexicana

Geomys spp.

Perognathus spp.

Neotoma spp.

Veotoma micropus

Sigmodon hispidus

Sylvilagus sp.

Lepus calfornicus

intilocapra

americana

docoileus

virginianus

3ison bison

docoileus or

Antilocapra
EXCAVATION UNITS

Common Name

Unidentified

fish

Catfish

Frog

Unidentified

turtle

Slider turtle

Box turtle

Unidentified

turtle

Water snake

Racer snake

Rat snake

Rattlesnake

Unidentified

bird

Vulture/large

raptor

Wild turkey

Heron

Roadrunner

Opossum

Raccoon

Coyote

Gray Wolf

Striped skunk

Ground

squirre1

Mexican ground squirre1

Pocket gopher

Pocket mouse

Pack rat

Southern plains

packrat

Cotton rat

Cottontail

Jackrabbit

Pronghorn

Whitetail deer

Bison

Deer or

Pronghorn
DECAVATION UNITS

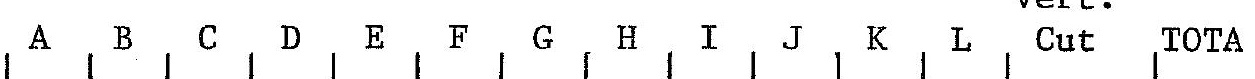


The pronghorn is found today in the western half of Texas and in the panhandle (Davis 1974:248), but was once found well into the lower Rio Grande Valley and along the lower Texas coast (Inglis 1964). In fact, some antelope populations persisted on the prairies of the lower coast until the mid-19th century (ibid.).

Bison appeared cyclically in central and southern Texas throughout prehistoric times (cf. Dillehay 1974). It appears that herds penetrated deep into southern Texas after A.D. 1200, and persisted in some numbers in northwestern south Texas, on the lower Guadalupe River, and on the grassy coastal prairies until the 17th century (cf. Hester and Parker 1970:21; Hester 1975a).

There has been no study made as yet to attempt to determine site seasonality based on the faunal remains. Davidson made general age estimates for most species, but provided no detailed comments. Both adult and juvenile bison remains are present (and, in terms of butchering practices, most skeletal elements appear to be represented). Davis (1974:264ff) has noted that bison ranged into Texas during the winter months. However, early Spanish accounts indicate that bison were present in south Texas during the early summer (cf. Campbel1 1975:18).

The faunal list (Table 2) indicates broad spectrum faunal utilization. The aquatic species-islider turtle, catfish, etc-indicate that Chiltipin Creek was probably a sluggish stream. At least they suggest a dependable water source in a creek that is today dry except after cloudbursts.

\section{MOLLUSCAN REMAINS}

Pelecypods. Although not abundant, fragments of freshwater mussels were scattered throughout the deposits. All are of the subfamily unionidae (cf. Burch 1975), but they have not been identified as to species. Most are so highly fragmented that such identification is probably impossible.

The aboriginal inhabitants probably gathered the mussels as a dietary supplement. The habitat for these pelecypods would have been a sluggish stream (or standing pools of water) in Chiltipin Creek. 
Gastropods. Five species of gastropods occurred at the Hinojosa site. Most were within the upper $30 \mathrm{~cm}$ of the deposit and were associated with the main concentrations of cultural debris. Based on evidence from archaeological finds in southern and southwestern Texas and on ethnohistoric accounts (T. N. Campbell, personal communication), it is felt that the larger gastropods (Rabdotus; see below) were gathered as a minor food supplement.

There were 2079 examples of the Rabdotus land snail (formerly Bulimulus; cf. R. schiedeanus or alternatus, with some examples of dealbatus). Mesodon snails (either thyroides or roemeri) numbered 307 specimens. The specimens at $41 \mathrm{JW} 8$ are generally less than $12 \mathrm{~mm}$ in diameter, and thus are smaller than the type specimens illustrated by Allen and Cheatum (1961:309).

The three other species of snails at the site were much less frequent. They included Polygyra texasiana (38 specimens), Helisoma trivolis (one specimen) and Physa anatina (one specimen).

All of the above snails are found in the area today, and this would seem to indicate that their habitats have not been radically changed since the time of aboriginal occupation. Rabdotus land snails are generally attributed to semi-arid areas, the Mesodon species to heavily wooded locales (cf. the riparian zone of Chiltipin Creek), and the Polygyra to open fields and woodlands. Helisoma and Physa are found in permanent or stagnant to semi-stagnant waters. 
SUMMARY AND RECOMMENDATIONS

This report has presented the results of archaeological investigations conducted at site 41 JW 8 (the Hinojosa site) in March 1975. Test excavations revealed midden deposits and cultural features dating to the Late Prehistoric period, ca. A.D. 1300. The prehistoric occupational remains are characterized by an artifact assemblage dominated by Perdiz arrow points, tiny end scrapers, and bone-tempered ceramics; the faunal assemblage is very extensive, with bison as one of the major species. The site deposits are relatively shallow, with most cultural debris concentrated in the upper $30 \mathrm{~cm}$. There is no evidence at the site of any previous (earlier) Late Prehistoric or Archaic occupations, and we are inclined to view the site as a single component of the 14th century A.D. The remains are varied enough, and the horizontal distribution of debris so wide, that the site can probably be interpreted as a preferred camping locality used on several occasions. The time span of site use is unknown, but we suspect it was fairly short, perhaps as a seasonal campsite during a period of a few years, or at the most, intermittently occupied over a few decades.

The cultural remains from the site can be put into perspective by a review of the "Archaeological Background" section found earlier in this report. The site has its closest affinities with Berclair (Hester and Parker 1970) and $41 \mathrm{ME} 19$ (Hester and Kelly 1976). In general, these (and other unpublished) sites reflect a pattern, datable to ca. A.D. 1300 and later, of occupations containing Perdiz arrow points, bone-tempered pottery and end-scrapers. Blade tools also are known to occur (cf. Hester and Parker 1970). Most striking is the occurrence of bison (and often, antelope) in the faunal collections from these sites. This situation has been discussed in some detail elsewhere (Hester 1975a). As noted in this earlier publication, these sites probably represent a heavier emphasis on bison (due to "bison population explosions" on the Great Plains at this time, forcing many of the herds southward; cf. Dillehay 1974:184), and perhaps an overall hunting technology which reflects a new orientation toward grassland-savannah fauna (e.g., bison and antelope).

Early historic documents indicate that much of the south Texas region was essentially grassland at the time of historic contact, with the spread of mesquite 
coming during the last century or two. Bison are known to have been present in southern Texas during the 18 th and 19 th centuries, surviving rather late on the coastal prairies (cf. Sjoberg 1953:8). Antelope persisted much longer, as Inglis (1964) has pointed out. A specific record of antelope survival indicates that small herds of antelope were present in grassland areas in Dimmit County (in the northern sector of south Texas) as late as the early 1900s (Vivion 1977). Vivion relates that "a herd of about 11 antelopes still existed" in the county around the turn of the century, but that by 1905 "practicaliy all of the animals were killed by the people, even though it was against the law." The last antelope in the herd was captured in 1907.

Dillehay (1974:Fig. 6) notes a southward push of bison between A.D. 12001300 and 1550. His data fit nicely with the emerging picture we have of bison herds (size unknown) extending into southern Texas at both ends of this time period and, based on the evidence presented here, as far south as Jim Wells County in deep south Texas. After A.D. 1400, probably fewer bison were present; for example, at Tortuga Flat (4I ZV 155) in Zavala County, Hill and Hester (1973) noted few bison remains, but there were abundant antelope and other faunal species. Bison were also present very late in the prehistoric or in early protohistoric times at $41 \mathrm{ME} 7$ (Scorpion Cave; cf. Hester 1975a: Table II), $41 \mathrm{ZV} \mathrm{60,} \mathrm{and} 41 \mathrm{ZV} 123$ (ibid.:Table I), and in Late Prehistoric or early Historic components such as the Kirchmeyer Site (41 NU 11) near Corpus Christi (ibid.:Table III).

Hester (1975a:122) has indicated that the spread of bison into southern Texas around A.D. 1200-1300 may have altered the lifeways of some of the resident populations. They, in essence, adopted a marginal Plains lifeway. It could also be argued that these sites dominated by bison remains represent hunting camps of marginal Southern Plains peoples (probably the ancestors of the Tonkawa) from the Edwards Plateau who may have followed the bison herds Into-southern Texas (cf. Hester and Parker 197Q). Which if indeed either, of these explanations is right we cannot possibly say at this time. What is evident, however, is that most contemporaneous Late Prehistoric populations in the region were affected to some extent by the bison intrusions and the cultural traits which appear to accompany this faunal phenomenon. For example, 
a limited number of bison remains are found at scattered sites (1ike Tortuga Flat) although there often is no indication that the species was heavily hunted. At these sites they were apparently not important in the subsistence system, perhaps because they were few in number or because some local groups did not develop the technology for killing them on any more than an occasional or random basis. Or, such sites may represent seasonal use at times of the year when bison did not range (in any numbers) into the area. Additionally, there are a wide range of lithic forms in these site assemblages (contrasted with the Perdiz, end scraper and blade tool assemblage in the "bison-oriented" sites). On the other hand, we do find widespread use of bone-tempered ceramics, the presence of "Plains" knives, and an increased frequency of end scrapers in many Late Prehistoric sites (see Hester and Hil1 1971 regarding ceramic distirbution). It would thus seem that a number of newly-introduced cultural traits were being rather widely diffused.

When we look at the Late Prehistoric in southern Texas, we are looking at a very limited time span of perhaps 400-500 years. We do not yet have enough radiocarbon dates to effectively separate, on a chronological basis, many of the disparate cultural assemblages that we have talked about in this section and in the earlier "Archaeological Background" portion. We need to also take into account the effects that short term climatic episodes may have had on these peoples during the Late Prehistoric. For example, our colleague, Joel D. Gunn, has pointed out a number of recent references dealing with specific climatic changes that may have affected the southern Texas region. Some of these changes (and resultant faunal and vegetational alterations) have been hinted at in earlier publications (cf. Price and Gunter 1943; Wel1s 1970), but research in the past few years dealing with the effect of sunspots on the earth's climate has produced more precise information. It is interesting to note that relatively severe winters are indicated for the period of ca. A.D. 1300-1500 (Eddy 1977:8). Accompanying these winters, perhaps, was the expansion of bison herds in southern Texas to a degree not previously known. A somewhat similar climatic situation is suggested by Alexander (1974:91), using data from Iceland for the past 1000 years. Iceland is considered a good indicator as to what was happening over all of the Northern Hemisphere, since that area is vulnerable to small temperature changes (ibid.). The 
Icelandic record indicates temperature drops between A.D. 1200 and 1400, a warming trend between A.D. 1400 and 1500, and rather drastic temperature drops between A.D. 1500 and 1700. These again, based on our admittedly scant data from south Texas, appear to correlate with records of bison presence. Matthews (1976:615) also suggests a considerably colder period roughly 500 years ago, with the increasingly lower temperatures beginning 800-900 years ago. Again, a very close correlation with the previously mentioned climatic data can be noted. How this cooler period, with notably colder winters, affected the lifeways, settlement patterns and subsistence systems of the Late Prehistoric peoples of southern Texas is an intriguing problem for future research. Perhaps it is one of the major causes that led to the changes we see with the end of the Archaic period ca. A.D. 1200.

At the beginning of this section, we speculated that Hinojosa was a single component site returned to over a period of years by the peoples of the same cultural tradition. The presence of bison in some numbers at the site would suggest that it is a winter-to-early-summer occupation (cf. Davis 1974:266). Functionally, it is suggested that it was primarily a bison-hunting camp, as indicated by the frequency of bison remains, and by the kinds of tools found in the Iithic assemblage there. The probable bison processing and/or bone disposal area in the southern portion of the site tends to support this assumption.

Hinojosa is obviously a highly significant site, and may hold the key to a number of the archaeological problems raised in this section. Extensive, open area excavations could provide (1) date on the internal structure of occupation; (2) a clue as to the span (and frequency) of occupation; (3) a better, overall view of faunal exploitation (and detailed faunal studies could better pin down the seasonality of site occupation and provide information on local climates); (4) a better chronological control on the site; and (5) information on many other problems, such as inter-group contacts in southern Texas, the environmental situation, and so forth. As noted previously, the site has been nominated to the National Register of Historic Places. It was approved by the State Review Board for nomination to the Register in January 1976. At the time of this writing (September 1977) no final decision had been made at the national level. 
Since the site lies within the detention poo1, and on the edge of the 50year sediment pool, of the proposed floodwater structure on Chiltipin Creek, we strongly urge further archaeological research at the site. A potential for damage exists to the site through reservoir construction (e.g., the widespread bulldozing that accompanies construction of this type of flood control project) or through long-term damage from inundation by floodwaters held within the floodwater retarding structure. Therefore, we believe that this important cultural resource must be thoroughly investigated. 



\section{ACKNOWLEDGMENTS}

A number of persons aided in this project. Gratitude is expressed to Logan Crews, formerly of the Temple office of the USDA Soil Conservation Service (SCS); to James Warren, SCS archaeologist; to John Roberts and his associates at the Alice office of the SCS; to Thomas C. Kelly and Leo C. Fletcher (of the Center staff); to General Leo Dusard (USAF Ret.) and to the late David Espy for their aid in excavation and site mapping; to John W. Clark, Jr. for handling the National Register nomination process; to Dr. V. M. Bryant, Jr. (Texas A\&M University) for palynological studies; to Billy Davidson for faunal analysis; and to Kathy McCauley, Jeanette Burch and Karen Moloney of the Center staff for their help in assembling this report. Edwin S. Harris and Anne A. Fox (of the Center staff) both contributed materially to this report; Harris carefully catalogued the collection from the site, and Fox aided the author in the ceramic analysis. Elizabeth Branch proofread the manuscript. 



\section{REFERENCES CITED}

Abbreviations Used

BTAS

$L T$

PA

TJS

UTSA-CAR

Bulletin of the Texas Archeological Society

La Tierra, Journal of the Southern Texas Archaeological Association

Plains Anthropologist

Texas Journal of Science

University of Texas at San Antonio, Center for Archaeological Research

-ASR Archaeological Survey Report

-SR Special Report

Alexander, T.

1974 Ominous Changes in the World's Weather. Fortune 89(2):90-95, $142,146,150,152$.

Allen, D. C. and E. P. Cheatum

1961 Ecological Implications of Fresh-Water and Land Gastropods in Texas Archeological Sites. BTAS 31 (for 1960):291-316.

Bames, V. E. (project director)

1976 Geologic Atlas of Texas, Laredo Sheet. Julia Gardner Memorial Edition. Bureau of Economic Geology, The University of Texas at Austin.

Blair, W. F。

1950 The Biotic Provinces of Texas. TJS 2(1):93-116.

Bogusch, E. R。

1952 Brush Invasion in the Rio Grande Plain of Texas. TJS 4(2):230-250.

Burch, J. B.

1975 Freshwater Unionacean Clams (Mollusca-Pelecypoda) of North

America. Malacological Publications, Hamburg, Michigan.

Campbe11, T. N.

1975 The Payaya Indians of Southern Texas. Special Publication 1, Southern Texas Archaeological Association. San Antonio. 
Corbin, J. E.

1974 A Model for Cultural Succession for the Coastal Bend Area of Texas. BTAS 45:29-54.

Davis, W. B.

1974 The Mammals of Texas. Revised Edition. Bulletin 41. Texas

Parks and Wildlife Department, Austin.

Dillehay, T. D.

1974 Late Quaternary Bison Population Changes on the Southern Plains. PA 19(65):180-196.

Eddy, J. A.

1977 The Case of the Missing Sunspots. Scientific American 236(5): $80-92$.

Hester, T. R.

1969 The Floyd Morris and Ayala Sites: Discussion and Comparison. In: Two Prehistoric Cemetery Sites in the Lower Rio Grande Valley of Texas. BTAS 40:157-166.

1970 An Interim Statement on Archaeological Research at Chaparrosa Ranch, Texas. Report submitted to the Office of the State Archeologist.

1971a Hafted Unifaces from Southwestern Coahuila, Mexico. The Kiva $36(4): 36-41$.

1971b Archaeological Investigations at the La Jita Site, Uvalde County, Texas. BTAS 42:51-148.

1974 Some Observations on Archaeology at Chaparrosa Ranch, 1974. LT $1(3): 19-22$.

1975a Late Prehistoric Cultural Patterns Along the Lower Rio Grande of Texas. BTAS 46:107-125.

1975b Chipped Stone Industries on the Rio Grande Plain of Texas. TJS $26(1-2): 213-222$. 
Hester, T. R. and F. A. Bass, Jr.

1974 An Archaeological Survey of Portions of the Chiltipin-San

Fernando Creeks Watershed, Jim Wells County, Texas. UTSACAR-ASR 4.

Hester, T. R. and T. C. Hill, Jr.

1971 An Initial Study of a Prehistoric Ceramic Tradition in Southern Texas. PA 16(52):195-203.

1975 Some Aspects of Late Prehistoric and Protohistoric Archaeology in Southern Texas. UTSA-CAR-SR 1.

Hester, T. R. and T. C. Kelly

1976 Archaeological Investigations at Sites Near Natalia, Medina County, Texas. UTSA-CAR-ASR 20.

Hester, T. R. and R. Parker

1970 The Berclair Site: A Late Prehistoric Component in Goliad County, Southern Texas. BTAS 41:1-24.

Hester, T. R. and H. J. Shafer

1975 An Initial Study of Blade Technology on the Central and Southern Texas Coast. PA 20(69):175-185.

Hi11, T. C. and T. R. Hester

1971 Isolated Late Prehistoric and Archaic Components at the Honeymoon Site (41 ZV 34), Southern Texas. PA 15(51):52-59.

1973 A Preliminary Report on the Tortuga Flat Site: A Protohistoric Campsite in Southern Texas. Texas Archeology 17(2):10-14.

Inglis, J. M.

1964 A History of Vegetation on the Rio Grande Plain. Texas Parks and Wildlife Bulletin 45.

MacNeish, R. S.

1958 Preliminary Archaeological Investigations in the Sierra de Tamaulipas, Mexico. Transactions of the American Philosophical Society $48(6)$. 
Matthews, S. W.

1976 What's Happening to Our Climate? National Geographic 150(5): 576-615.

Metcalf, G.

1970 Some Wooden Scraper Handles from the Great Plains and the Southwest. PA 15(47):46-53.

Montgomery, J. L.

1977 The Mariposa Site: A Late Prehistoric Site on the Rio Grande Plain of Southern Texas. Unpublished M.A. thesis, Texas Tech University.

Nunley, J. P.

1975 Report of Archaeological Survey Activities 1975. In: Archaeology and Ethnohistory of the Gateway Area, Middle Rio Grande of Texas, Report of the 1975 Investigations:40-47. Report submitted to the National Endowment for the Humanities by The University of Texas at San Antonio.

1976 Report on the Second Season's Survey of Archaeological Resources in the Vicinity About Guerrero, Coahuila, Mexico. In: The Archaeology and Ethnohistory of the Gateway: Middle Rio Grande of Texas, Report of the 1976 Investigations (assembled by R. E. W. Adams:38-41. Report submitted to the National Endowment for the Humanities by The University of Texas at San Antonio.

Nunley, P. and T. R. Hester

1975 An Assessment of Archaeological Resources in Portions of Starr County, Texas. UTSA-CAR-ASR 7.

Patterson, L. W.

1974 Three Sites in Jim Wells County. LT 1(2):12-14.

Pool, W. C.

1975 A Historical Atlas of Texas. The Encino Press, Austin.

Prewitt, E. R.

1974 Preliminary Archeological Investigations in the Rio Grande Delta of Texas. BTAS 45:55-66. 
Price, W. A. and G. Gunter

1943 Certain Recent Geological and Biological Changes in South Texas, with Consideration of Probable Causes. Proceedings and Transactions of the Texas Academy of Science 1942:3-21.

Ralph, E. K., H. N. Michael and M. C. Han

1973 Radiocarbon Dates and Reality. MASCA Newsletter 9(1).

Sjoberg, A. F.

1953 Lipan Apache Culture in Historical Perspective. Southwestern. Journal of Anthropology 9(1):76-98.

Texas Almanac

1975 A. H. Belo Corporation, Dallas.

Vivion, L.

1977 The Last Antelope in Dimmit County. In: Treasures of Dimmit

County. Carrizo Springs (Texas) High School English Department (mimeographed; not paginated).

Wedel, W.

1970 Antler Tine Scraper Handles from the Central Plains. PA 15(47): $36-45$.

Weeks, A. W.

1933 Lissie, Reynosa, and Upland Terrace Deposits of Coastal Plain of Texas Between Brazos River and Rio Grande. Bulletin of the American Association of Petroleum Geologists $17(5): 453: 487$.

1945 Quaternary Deposits of Texas Coastal Plain Between Brazos River and Rio Grande. Bulletin of the American Association of Petroleum Geologists $29(12): 1693-1720$.

Wells, P. V.

1970 Historical Factors Controlling Vegetation Patterns and Floristic Distributions in the Central Plains Region of North America. In: Pleistocene and Recent Environments of the Central Great Plains. Department of Geology, University of Kansas, Special Publication 3. 
